\title{
Identification and Characterization of Antidepressant-Sensitive Serotonin Transporter Proteins Using Site-Specific Antibodies
}

\author{
Yan Qian, ${ }^{1,2}$ Haley E. Melikian,, ${ }^{1,2}$ David B. Rye, ${ }^{3}$ Allan I. Levey, ${ }^{3}$ and Randy D. Blakely ${ }^{2}$ \\ ${ }^{1}$ Graduate Program in Neuroscience, and Departments of ${ }^{2}$ Anatomy and Cell Biology, and ${ }^{3}$ Neurology, Emory \\ University School of Medicine, Atlanta, Georgia 30322
}

Serotonin (5HT) transporters (SERTs) are responsible for clearance of synaptic and plasma $5 \mathrm{HT}$ and are molecular targets for multiple therapeutic and addictive compounds. Recently brain and peripheral SERT cDNAs have been cloned and characterized functionally in transfected cells. Antipeptide (S365) and anti-fusion protein (CT-2) antibodies, directed at epitopes poorly conserved among other $\mathrm{Na}^{+} / \mathrm{Cl}^{-}$cotransporters, have been prepared to facilitate the identification and characterization of SERT proteins in native and transfected cells. Immunoprecipitations and immunoblots of rat/human SERT-transfected HeLa cells reveal specific SERT-immunoreactive glycoproteins absent from extracts of vector-transfected cells and absent when incubations were conducted using peptide- or fusion protein-absorbed antibody. In SDS-PAGE of membranes prepared from rat midbrain and cortex, SERTs migrate as single $76 \mathrm{kDa}$ polypeptides with a relative abundance consistent with the known distribution of 5HT neurons and axonal projections. SERT-immunoreactive proteins are also detectable in platelet and pulmonary membranes, sites of peripheral 5HT uptake, but not in liver. Our studles also Indicate that brain and platelet SERTs are formed from identical polypeptides differing significantly in their extent of $\mathrm{N}$-linked glycosylation. Immunocytochemistry performed on rat brain sections with CT-2 antibody revealed SERT expression associated with brainstem raphe nuclei in a pattern virtually identical to that obtained by labeling adjacent sections with $5 \mathrm{HT}$ antisera. SERT-immunoreactive fibers were found to be widely distributed throughout the rodent brain, with highest density in forebrain regions known to receive a dense serotonergic innervation. In a similar manner, CT-2 antibody also detects endogenous expression of human SERT proteins, providing an opportunity for future studies on the modulation of transporter protein expression in neurologic and psychiatric disorders.

Key words: midbrain, platelet, immunoblot, glycosylation, immunocytochemistry, raphe nuclei]

\footnotetext{
Received May 5, 1994; revised June 28, 1994; accepted Aug. 2, 1994.

We thank K. R. Moore, A. L. Bauman, C. Heilman, B. Ciliax, H. Rees III, T. Steininger, A. Serbanescu, and M. Owens for technical assistance and helpfu discussions during the completion of these studies. We thank $H$. Niznik for donation of hDAT cDNA. This work was supported in part by NIH Grants DA-07390 (R.D.B.) and AG-10130 (A.I.L.), and the Mallinckrodt Foundation (R.D.B.).

Correspondence should be addressed to Randy D. Blakely at the above address.

Copyright (c) 1995 Society for Neuroscience $0270-6474 / 95 / 151261-14 \$ 05.00 / 0$
}

$\mathrm{Na}^{+}$- and $\mathrm{Cl}^{-}$-coupled serotonin (5-hydroxytryptamine, 5HT) transporters (SERTs) exist on the plasma membrane of serotonergic presynaptic terminals and play a prominent role in terminating the action of synaptically released 5HT (Ross et al., 1967; Kuhar et al., 1972; O'Reilly and Reith, 1988; Bruns et al., 1993). Blockade of 5HT transport by tricyclic and heterocylic antidepressants results in an acute elevation of extracellular 5IIT and an amelioration of a variety of neuropsychiatric disorders (Fuller and Wong, 1989; Barker and Blakely, 1994; Owens and Nemeroff, 1994). SERTs are also molecular targets for cocaine and addictive amphetamines, including 3,4-methylenedioxymethamphetamine (MDMA, "ecstasy") (Blakely et al., 1991a; Hoffman et al., 1991). In addition to their synthesis by serotonergic neurons, SERTs are also displayed on plasma membranes of platelets (Sneddon, 1973; Rudnick, 1977), pulmonary endothelium (Gillis, 1985), and placental brush border epithelia (Balkovetz et al., 1989), where they participate in systemic 5HT homeostasis (see Fozard, 1989).

Recently, cDNAs encoding functional SFRTs have been cloned from rat brain (rSERT; Blakely et al., 1991a) and basophilic leukemia (RBL) cells (Hoffman et al., 1991), mouse brain (Chang et al., 1994), and human placenta (hSERT; Ramamoorthy et al., 1993). Sequence identity of brain and RBL cDNAs indicates that neural and non-neural SERTs are encoded by a common gene, an hypothesis supported by the identification of single SERT loci in human (Ramamoorthy et al., 1993) and mouse (Gregor et al., 1993). Furthermore, SERTs encoded by human platelet and hrain RNAs appear to be identical (I esch et al., 1993b,c). Rodent and human SERTs are predicted to be encoded by subunits of 630 amino acids with $>90 \%$ cross-species identity. Hydropathy analysis suggests that SERTs exhibit a topology of 12 transmembrane domains (TMDs) with a large extracellular loop between TMDs 3 and 4 that contains sites for $\mathrm{N}$-linked glycosylation. $\mathrm{NH}_{2}-$ and $\mathrm{COOH}$-termini are predicted to lie in the cytoplasm. This topology is characteristic of other members of the $\mathrm{Na}^{+} / \mathrm{Cl}^{-}$-dependent transporter gene family whose substrates include other neurotransmitters, neuromodulators, and osmolytes (Amara and Kuhar, 1993; Rudnick and Clark, 1993). SERTs are most closely related to the norepinephrine and dopamine transporters (NETs and DATs), with greatest sequence divergence present in $\mathrm{NH}_{2}$ - and $\mathrm{COOH}$-termini as well as in the large TMD3-4 extracellular loop (Amara and Kuhar, 1993; Rudnick and Clark, 1993).

Whereas brain and peripheral SERTs are predicted to be encoded by identical polypeptides, little information exists to describe the extent and diversity of SERT post-translational modifications, nor have SERT proteins been visualized in situ. These 
issues are magnified by the frequent use of platelet SERTs as a model for the behavior of brain SERTs in disease states (Stahl, 1977; Da Prada et al., 1988; Ellis and Salmond, 1994). Alterations in 5HT transport and/or antidepressant binding have been reported in platelet and/or brain from patients with major neurologic and psychiatric disorders, including depression and suicide (Tuomisto et al., 1976; Meltzer et al., 1981; Paul et al., 1981; Stanley et al., 1982), geriatric depression (Nemeroff et al., 1988), Parkinson's disease (Raisman et al., 1986; D'Amato et al., 1987b), alcoholism (Daoust et al., 1991), schizophrenia (Kaplan and Mann, 1982; Joyce et al., 1993), and progressive supranuclear palsy (Chinaglia et al., 1993). However, the inability to evaluate structural changes in SERT protein has limited interpretation of these observations at a molecular level. Furthermore, the cellular localization of SERTs has, until now, been indirectly inferred from ${ }^{3} \mathrm{H}-5 \mathrm{HT}$ uptake studies (Björkland et al., 1973; Azmitia and Marovitz, 1980) or autoradiographic paradigms with brain sections using radiolabeled serotonin transporter antagonists (Fuxe et al., 1983; D'Amato et al., 1987a; De Souza et al., 1987; Hrdina et al., 1990; Chen et al., 1992). $1 \mathrm{l}$ though this approach can provide sensitive quantitative analyses of SERTs in post-mortem brain sections, interpretation relies upon the absolute identity of SERT antagonist-binding sites with transporter proteins (D'Amato et al., 1987a; Marcusson, 1990; Duncan et al., 1992), and the autoradiographic technique provides only limited subcellular resolution. Thus, controversy exists as to whether SERTs in brain are exclusively neuronal or are expressed as well on glial membranes surrounding serotonergic synapses (Anderson et al., 1992). Below we present our efforts to identify, characterize, and visualize SERT proteins in rat and human brain and peripheral tissues using specific, sitedirected polyclonal antibodies.

\section{Materials and Methods}

Production of SERT antisera. For production of antipeptide antibody S365, a synthetic peptide corresponding to amino acids 388-401 (EMRNEDVSEVAKDA, see Fig. 1) and containing an additional $\mathrm{COOH}$-terminal cysteine for carrier conjugation was synthesized and purified by reverse-phase HPLC at the Emory University Microchemical Facility. S365 peptide was coupled to keyhole limpet hemocyanin (KLH) or bovine serum albumin (BSA) carrier proteins (Sigma, St Louis, MO) by maleimide cross-linking to free sulfhydryl groups as previously described (Melikian et al., 1994). For production of antifusion protein antibody CT-2, a 102 bp segment of rSERT encoding the terminal 34 amino acids of the transporter's COOH-terminus was amplified by polymerase chain reaction (Saiki, 1987) using oligonucleotides containing restriction sites compatible with the pGEX2T fusion protein expression plasmid (Pharmacia, Piscataway, NJ; Smith et al., 1988). Oligonucleotides utilized were 5'-GCGCGCGGATCCCTGATCAGCACTCCGGGGACA-3' (sense) and 5'-GCGCGCGAATTCTTACACAGCATTCATGCTGAT- $3^{\prime}$ (antisense). After digestion with BamHI and EcoRI, the amplified fragment was cloned into pGEX2T and sequence verified via the dideoxy chain termination sequencing method of Sanger (1977). The resulting plasmid encodes a modified glutathione S-transferase (GST) fusion protein fused in frame with the SERT COOH-tcrminal fragment. SERT fusion protein was harvested from transformed $E$. coli strain BL21 after IPTG induction and purified by affinity chromatography following the methods described by Levey et al. (1991). The purified fusion protein migrated as a single band by SDS-PAGE as revealed by Coomassie blue staining.

Rabbit immunization and antibody purification. Female New Zealand white rabbits were maintained and immunized with peptide conjugates or fusion protein by Spring Valley Labs (Sykesville, MD). For peptide antibody production, primary immunization with S365 peptide-KLH conjugate $(1000 \mu \mathrm{g})$ emulsified in complete Freund's adjuvant was followed by 14 and $28 \mathrm{~d}$ booster injections $(500 \mu \mathrm{g})$ in incomplete Freund's adjuvant. Thereafter, monthly boosts were given as $500 \mu \mathrm{g}$ in incomplete Freund's adjuvant. Blood was collected, and serum isolated
1-2 weeks following boosts and stored at $-20^{\circ} \mathrm{C}$. Studies reported reflect sera harvested $2-3$ months after the initial immunization. For fusion protein antibody production, primary immunizations with SERT fusion protein $(500 \mu \mathrm{g})$, emulsified as described above, were repeated 2 weeks later, followed by monthly $100 \mu \mathrm{g}$ boosts. Sera were obtained and stored as above. All studies reported with $\mathrm{CT}-2$ antibody were conducted with sera derived 6 weeks after the initial immunization.

Immunoreactivity of S365 antisera was determined by ELISA on BSA-peptide conjugates as described by Harlow and Lane (1988). S365 antisera was utilized for immunoprecipitation without further purification. CT-2 antibody immunoreactivity was assessed by immunoprecipitations of rSERT- or hSERT-transfected cells using unpurified serum and by immunoblots (see below) after purification by affinity chromatography. For initial purification of fusion protein antisera, a column was made by coupling bacterial lysates (124 mg protein) from BL21 cells previously induced to express only GST with a $1: 1$ mixture (2.5 $\mathrm{ml}$ each) of Affi-10 and Affi-15 beads (Bio-Rad, Hercules, CA) according to manufacturer's methods. A SERT fusion column was made by coupling $4 \mathrm{mg}$ fusion protein onto $0.5 \mathrm{ml}$ of Affi- 15 beads. Serum was first preadsorbed over the GST/BL21 column and the flow through was applied to the SERT fusion protein column. After washing the column with $10 \mathrm{~mm}$ Tris, $\mathrm{pH} 8.0$, the anti-SERT component was eluted with $100 \mathrm{~mm}$ glycine, $\mathrm{pH} 3.0$, and neutralized with $1 / 10$ volume of 1 $\mathrm{M}$ Tris, $\mathrm{pH}$ 8.0. O.D. ${ }_{280}$ was used to monitor and quantitate the protein concentration of eluted fractions ( 1 O.D. $=1 \mu \mathrm{g} / \mu \mathrm{l}$ protein).

Transient expression of transporter cDNAs in HeLa cells. TSERT, hSERT, human NET (hNET), and human DAT (hDAT) cDNAs were transfected into HeLa cells using the vaccinia-T7 expression system (Fuerst et al., 1986; Blakely et al., 1991b). pBluescript SKII (Stratagene, La Jolla, CA) transfections were performed in parallel as a negative control for transporter expression. Briefly, 6-well tissue culture plates were seeded with HeLa cells (American Type Tissue Collection, Rockville, MD) $1 \mathrm{~d}$ before transfection. Media was removed and virus $\left(\mathrm{VTF}_{7-3}, 10 \mathrm{pfu} / \mathrm{cell}\right)$ was added to cells in OPTI-MEM (Life Technologies, Gaithersburg. MD) supplemented with $55 \mu \mathrm{M} 2$-mercaptoethanol for $30 \mathrm{~min}$, followed by addition of DNA as a liposome suspension with a 3:1 lipid to DNA ratio (Lipofectin; Life Technologies). Immunoprecipitations were performed using $3 \times 10^{5}$ cells transfected with 5 $\mu \mathrm{g}$ DNA, whereas immunoblots utilized $10^{6}$ cells transfected with 10 $\mu \mathrm{g}$ DNA. Transfected cells were harvested 7 or $14 \mathrm{hr}$ following transfection for immunoprecipitation and immunoblots, respectively. Transport of 5-hydroxy-G- ${ }^{3} \mathrm{H}$-tryptamine creatinine sulfate $(8.6 \mathrm{Ci} / \mathrm{mmol}$; Amersham, Buckinghamshire, England), 1-ring 2,5,6- ${ }^{3} \mathrm{H}$-norepinephrine (NE, $48.6 \mathrm{Ci} / \mathrm{mmol}$; DuPont-New England Nuclear, Wilmington, DE), and $7,8-{ }^{3} \mathrm{H}$-dopamine (DA, $45 \mathrm{Ci} / \mathrm{mmol}$; Amersham) was assayed as previously described (Blakely et al., 1991a; Pacholczyk et al., 1991; Ramamoorthy et al., 1993).

Immunoprecipitation. Four hours post-transfection, cells were washed with prewarmed Met/Cys-free media (ICN, Irvine, CA) and labeled with $500 \mu$ l prewarmed Tran- ${ }^{35} \mathrm{~S}$ label $(1131 \mathrm{Ci} / \mathrm{mmol}, 50 \mu \mathrm{Ci} / \mathrm{ml} ; \mathrm{ICN})$ in $\mathrm{Met} / \mathrm{Cys}$-free media $\left(3 \mathrm{hr}, 37^{\circ} \mathrm{C}\right)$. For experiments examining the effects of tunicamycin on SERT biosynthesis in HeLa cells, tunicamycin $(10 \mu \mathrm{g} / \mathrm{ml}$; Sigma) or vehicle were added to cells both at the time of transfection as well as during the media change to initiate metabolic labeling. Labeled media was removed and whole cell extracts prepared by washing cells three times in $\mathrm{Na}$ phosphate-buffered saline, $\mathrm{pH} 7.4$, and solubilizing in RIPA buffer (10 mM Tris, pH 7.4, $150 \mathrm{~mm} \mathrm{NaCl}, 1$ mM EDTA, $0.1 \%$ SDS, $1 \%$ Triton X-100, $1 \%$ Na deoxycholate) supplemented with protease inhibitors $(1 \mathrm{mg} / \mathrm{ml}$ soybean trypsin inhibitor, $1 \mathrm{mM} o$-phenanthroline, $1 \mu \mathrm{g} / \mathrm{ml}$ leupeptin, $1 \mathrm{~mm}$ iodoacetamide, $1 \mu \mathrm{M}$ pepstatin A, and $250 \mu \mathrm{M}$ PMSF; all from Sigma) for $30 \mathrm{~min}$ at $4^{\circ} \mathrm{C}$ with shaking. S365 or CT-2 antisera $(5 \mu \mathrm{l})$ were added to the labeled cell extracts $(300 \mu \mathrm{l})$ and samples incubated with continuous mixing (1 $\mathrm{hr}, 22^{\circ} \mathrm{C}$ ). Protein A-Sepharose beads (Pharmacia) were preblocked by incubation with unlabeled HeLa cell extract $\left(1 \mathrm{hr}, 22^{\circ} \mathrm{C}\right)$, followed by three washes and resuspension to $30 \mathrm{mg} / \mathrm{ml}$ in RIPA buffer. Blocked beads $(100 \mu \mathrm{l})$ were added to labeled cell extracts and incubated for either $1 \mathrm{hr}$ at $22^{\circ} \mathrm{C}$ or overnight at $4^{\circ} \mathrm{C}$, followed by washing as above, and bound protein was eluted into $100 \mu \mathrm{l}$ Laemmli sample buffer ( 15 $\min , 22^{\circ} \mathrm{C}$ ). Following bead centrifugation, supernatants were subjected to SDS-PAGE (Laemmli, 1970). Gels were soaked in Entensify enhancing solution (Dupont-New England Nuclear), dried, and exposed to $\mathrm{x}$-ray film at $-80^{\circ} \mathrm{C}$. Control immunoprecipitations were conducted with preimmune serum and $S 365$ serum incubated with $S 365$ peptide $(10 \mu \mathrm{M})$. 
Membrane preparations and immunoblots. Twelve hours after transfection, HeLa cells were washed, scraped into PBS, and harvested by centrifugation. Cell pellets were resuspended in $10 \mathrm{~mm}$ Tris, $1 \mathrm{~mm}$ EDTA (TE), pH 7.2, containing protease inhibitors, homogenized, assayed for protein content, and stored at $-20^{\circ} \mathrm{C}$ at $\sim 1 \mathrm{mg} / \mathrm{ml}$ protein. Prior to SDS-PAGE, membranes were collected at $21,000 \times \mathrm{g}$. For characterization of SERT expression in primary tissues, male SpragueDawley rats were killed by rapid decapitation, and tissues dissected, and homogenized in TE buffer plus protease inhibitors. Homogenates were centrifuged at low speed $(20 \times g)$ to remove particulate debris, and membranes were pelleted from the supernatants at $21,000 \times g$ for 20 min. Membrane pellets were resuspended in TE buffer plus protease inhibitors and stored at $-80^{\circ} \mathrm{C}$. Purified membranes from rat platelets were prepared as described by Nemeroff et al. (1988). Sample protein concentration was determined by the Bradford method (Bio-Rad) using BSA as standard. Membrane pellets were solubilized in 10\% SDS for $1 \mathrm{hr}$ at room temperature followed by treatment with Laemmli sample buffer for $20 \mathrm{~min}$. Solubilized proteins were separated by SDS-PAGE ( $10 \%$ separating gel) and then electroblotted onto PVDF membrane $(0.45 \mu \mathrm{m}$, Millipore, Bedford, MA) at $150 \mathrm{~mA}$ for $16 \mathrm{hr}$ in transfer buffer (25 mM Tris, $192 \mathrm{~mm}$ glycine). Subsequently, blots were preblocked with 5\% nonfat dried milk in PBS and incubated with affinitypurified CT-2 antibody $(1 \mu \mathrm{g} / \mathrm{ml})$ in new blocking solution overnight at $4^{\circ} \mathrm{C}$. Blots were incubated with horseradish peroxidase (HRP)-conjugated goat anti-rabbit IgG $(1: 10,000$; Bio-Rad) for $1 \mathrm{hr}$ at room temperature and developed using enhanced chemiluminescence (Amersham). Prcstaincd molccular mass markers (Bio-Rad) were used to determine $M_{r}$ of immunoreactive species. For preabsorption experiments, CT-2 antibody was preincubated with or without SERT fusion protein-conjugated Affi- 15 beads $(1 \mu \mathrm{g} / \mathrm{ml}$ antibody to $100 \mu \mathrm{g} / \mathrm{ml}$ fusion protein) at room temperature for $1 \mathrm{hr}$ prior to use.

To examine the extent of $\mathrm{N}$-linked glycosylation of rSERT, membranes from rat brain $(50 \mu \mathrm{g}$ membrane protein), platelet $(50 \mu \mathrm{g} \mathrm{mem-}$ brane protein), and rSERT cDNA-transfected HeLa cells (25 $\mu \mathrm{g}$ whole cell protein) were pelleted, resuspended in $20 \mu \mathrm{l}$ TE containing protease inhibitors, and incubated with PNGase F ( $800 \mathrm{U} / \mu \mathrm{l}$; New England Biolabs, Beverly, MA) at $37^{\circ} \mathrm{C}$ for $4 \mathrm{hr}$. Deglycosylated membranes were repelleted, dissolved in SDS as described above, and subjected to SDSPAGE/immunoblot.

Immunocytochemistry. Male Sprague-Dawley rats $(n=6)$ were deeply anesthetized with Nembutal $(200 \mathrm{mg} / \mathrm{kg}$, Abbot Laboratories, Chicago, IL) and perfused through the aorta with $\mathrm{Ca}^{2+}$-free Tyrode's solution $\left(137 \mathrm{~mm} \mathrm{NaCl}, 2.7 \mathrm{mM} \mathrm{KCl}, 0.83 \mathrm{mM} \mathrm{MgCl}_{2}, 3.5 \mathrm{~mm}\right.$ $\mathrm{Na}_{2} \mathrm{HPO}_{4}, 8.3 \mathrm{mM} \mathrm{NaH} \mathrm{PO}_{4}, 5.6 \mathrm{~mm} \mathrm{D}$-glucose, $\mathrm{pH}$ 7.4) containing 50 units/ml heparin sulfate (Sigma), followed by $0.1 \mathrm{M}$ Na phosphate-buffered 4\% paraformaldehyde (Fisher, Pittsburgh, PA), pH 7.6, with or without $0.15-0.3 \%$ glutaraldehyde (Electron Microscopy Sciences, Fort Washington, PA). Animals were then perfused sequentially with $10 \%$ and $30 \%$ sucrose dissolved in $0.1 \mathrm{~m}$ Na phosphate buffer. Brains were removed and cryoprotected in $30 \%$ sucrose for $48 \mathrm{hr}$ at $4^{\circ} \mathrm{C}$ and then sectioned at $40 \mu \mathrm{m}$ on a freezing stage sliding microtome. Tissue sections werc collected into $0.05 \mathrm{~m}$ Tris-buffered saline (TBS), $\mathrm{pH} 7.4$, Sections were preblocked in TBS containing $4 \%$ normal goat serum (NGS, Organon Teknika, West Chester, PA) and $0.1 \%$ Triton X-100 (Sigma) for at least $1 \mathrm{hr}$ at $4^{\circ} \mathrm{C}$, and then incubated with affinity-purified CT-2 antibody (0.25-0.5 $\mu \mathrm{g} / \mathrm{ml}$ in TBS containing 4\% NGS) for $48 \mathrm{hr}$ at $4^{\circ} \mathrm{C}$. SERT immunoreactivity was detected with the Vectastain $A B C$ Elite kit (Vector Laboratories, Burlingame, CA) using biotinylated goat anti-rabbit $\operatorname{IgG}\left(1: 200 ; 16 \mathrm{hr}\right.$ at $\left.4^{\circ} \mathrm{C}\right)$ and the avidin-biotin-peroxidase complex $\left(1: 50 ; 4 \mathrm{hr}\right.$ at $\left.4^{\circ} \mathrm{C}\right)$. HRP reaction product was processed with $0.5 \mathrm{mg} / \mathrm{ml}$ diaminobenzidine (Sigma) and $0.01 \% \mathrm{H}_{2} \mathrm{O}_{2}$. The developed sections were mounted on Superfrost Plus slides (Fisher), dried and dehydrated through graded ethanols, soaked in Histo-Clear (National Diagnostics, Atlanta, GA), and coverslipped for microscopic examination. Control incubations consisted of omission of primary antibody or incubations conducted with fusion protein $(100 \mu \mathrm{g} / \mathrm{ml})$-absorbed CT-2 antibody. Adjacent sections were also incubated with polyclonal rabbit anti-5HT antibody (1:20,000; Incstar, Stillwater, MN), and immunoreactivity visualized as described for $\mathrm{C}^{\prime} \mathrm{I}-2$ antibody.

Human brains were obtained postmortem from four individuals (range of post-mortem interval from 2.5 to $9 \mathrm{hr}$ ), and $1 \mathrm{~cm}$ blocks of mesopontine tegmentum or temporal lobe were fixed by immersion in cold $4 \%$ paraformaldehyde in $0.1 \mathrm{M}$ sodium phosphate buffer, $\mathrm{pH} \mathrm{7.2,}$ for 24-36 hr. Blocks were then transferred to $10 \%$ sucrose in the same buffer for at least $3 \mathrm{~d}$ and then sectioned and processed for SERT immunoreactivity with CT-2 antibody as described above, with the following modifications. Sections were pretreated with $3 \%$ hydrogen peroxide and $1 \%$ Triton in $0.05 \mathrm{M}$ TBS for $30 \mathrm{~min}$ to inhibit endogenous peroxidase, rinsed five times in TBS, and then processed in avidin D and biotin solutions (Blocking Kit, Vector Laboratories, Inc.) to reduce background. A mixture of $4 \%$ each human and goat sera were used in preblock and other antibody-containing steps.

\section{Results}

\section{Characterization of SERT antibodies}

Comparative analysis of rodent and human SERT cDNA inferred amino acid sequences revealed that the loops between several putative TMDs as well as the $\mathrm{NH}_{2}$ and $\mathrm{COOH}$ tails are regions highly conserved across SERTs but divergent with other gene family members. These regions are also most likely to be exposed to aqueous compartments for antibody recognition. Accordingly, a synthetic peptide (S365), derived from a putative external loop between TMDs 7 and 8 (Fig. 1) that is absolutely conserved across cloned rat (Blakely et al., 1991a; Hoffman et al., 1991), mouse (Chang et al., 1994), and human (Ramamoorthy et al., 1994) SERTs, was coupled to KLH for rabbit immunization. S365 antisera, but not preimmune sera (Fig. 2), specifically immunoprecipitated a $61 \mathrm{kDa}$ protein species from ${ }^{35}$ S-Met/Cys metabolically labeled rSERT-transfected HeLa cells. Immunoprecipitation products were absent from extracts prepared from control vector (pBluescipt SKII)-transfected HeLa cells. In addition, recovery of the $61 \mathrm{kDa}$ species from rSERT-transfected HeLa cells was abolished by co-incubation of S365 antibody with the immunizing peptide. Co-incubation of antisera with a different peptide derived from a distinct region of the rSERT sequence failed to block immunoprecipitation (data not shown). S365 antisera also immunoprecipitated an equivalently sized protein from hSERT-transfected HeLa cells. Further attempts, however, to utilize the S365 antibody for immunoblot or immunocytochemical detection of endogenous SERT proteins proved unsuccessful.

To improve our chances of identifying more powerful SERT antibodies, a GST fusion protein comprising 34 amino acids of the rSERT COOH-terminus was synthesized in $E$. coli as described in Materials and Methods. The region selected for fusion protein production (see Fig. 1) is absolutely conserved between rat and mouse, exhibits only three amino acid differences from rat to human, and possesses only $29 \%$ identity with the $\mathrm{COOH}-$ terminus of the human norcpincphrinc transporter (Pacholzyk et al., 1991), the most closely related SERT homolog. Following a repetitive absorption procedure to remove E. coli- and GSTtargeted antibodies, SERT fusion protein-specific antibodies (CT-2) were purified by affinity chromatography. On immunoblots, affinity-purified CT-2 antibody detected the SERT-GST fusion protein but not GST itself nor any proteins derived from E. coli lysates (Fig. 3A).

Immunoprecipitation of metabolically labeled rSERT-transfected HeLa cells with affinity-purified CT-2 antibody yielded a $61 \mathrm{kDa}$ species identical in migration to that described above for S365 immunoprecipitations (data not shown). Of greater significance, CT-2 antibody proved capable of recognizing denatured rSERT protein as demonstrated by immunoblots of transfected HeLa cell membrane extracts subjected to SDS-PAGE (Fig. $3 B$ ). In short exposures, a single immunoreactive species was evident in membranes from both rat and human SERT-transfected cells, but was absent from membranes of vector- or hNET-transfected cells. CT-2 antibody also exhibited no crossreactivity with proteins from extracts of hDAT-transfected HeLa 


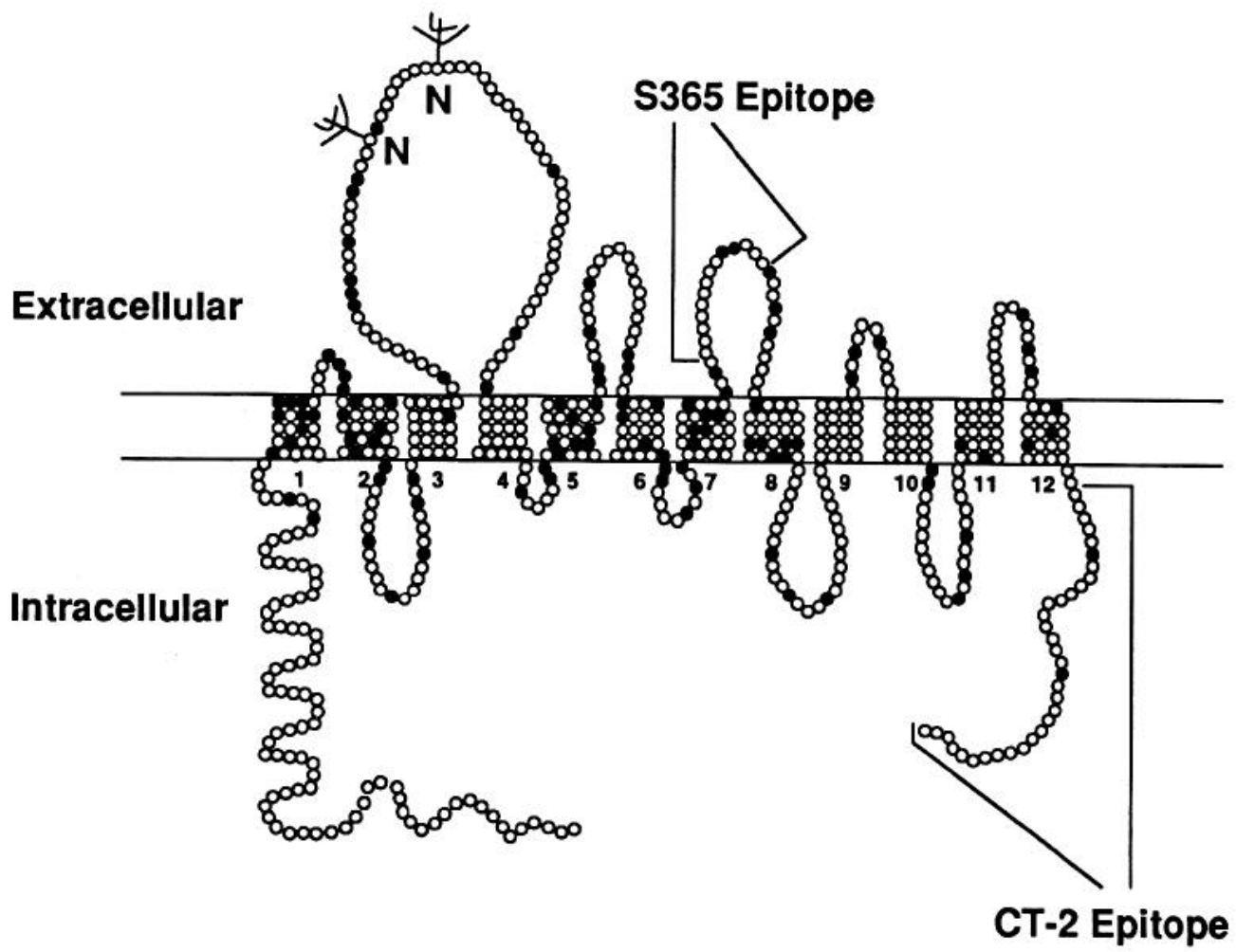

Figure 1. Schematic diagram of SERT antibody epitopes. The $630 \mathrm{ami}-$ no acid polypeptide predicted from rat and human SERT cDNAs (Blakely et al., 1991, 1992; Hoffman et al., 1991) is shown with 12 putative transmembrane domains as indicated by hydrophobicity analysis. $\bullet$ represent amino acids absolutely conserved across the $\mathrm{Na}^{+} / \mathrm{Cl}^{-}$cotransporter gene family. $N$ designates the position of asparagine residues in canonical $\mathrm{N}$-glycosylation sites. The S365 antipeptide antibody is directed at rSERT amino acids 388401 , whereas CT-2 fusion protein antibody is directed at the final 34 amino acids (597-630) of the $\mathrm{COOH}$-terminus.

vealed two additional immunoreactive bands (90 and $200 \mathrm{kDa})$ absent from vector-transfected cells (Fig. $3 D$ ). The 90 and 200 $\mathrm{kDa}$ species were also faintly evident in immunoprecipitations of metabolically labeled transfected cells (Fig. 2). CT-2 immunoreactivity was absent from immunoblots conducted with antibody preabsorbed with SERT fusion protein (Fig. $3 C, D$ ). In addition, immunoblot immunoreactivity was not diminished by incubations conducted with an equivalent amount of the GST protein lacking the rSERT $\mathrm{COOH}$-terminal fragment, nor did preimmune sera yield visible immunoreactivity (data not shown).

\section{Detection of endogenous SERT protein expression}

The ability to detect directly unlabeled, denatured SERT proteins by immunoblot offered an opportunity to visualize endogenous SERT protein expression. Thus, membrane extracts from rat brain and selected peripheral tissues were immunoblotted with affinity-purified CT-2 antibody as described for SERT-transfected HeLa cells. Single CT-2-immunoreactive species of $76 \mathrm{kDa}$ were detected in cortex and midbrain, but not in cerebellum (Fig. $4 A$ ). Among the peripheral tissues examined, platelet membranes displayed prominent SERT immunoreactivity. On short exposures, platelet immunoreactivity appeared as a single $94 \mathrm{kDa}$ band. An $80 \mathrm{kDa}$ CT-2-immunoreactive band was also present in pulmonary membranes, although relatively long exposures were required to visualize this species. SERT-immunoreactive bands were absent from liver membrane extracts. As with blots from transfected cells, antibody recognition of endogenous SERTs was abolished by preincubation with SERT fusion protein (Fig. 4B). Immunoblots of membranes prepared from human platelet and brain displayed immunoreactive SERT bands comparable in size to that observed with rat tissues (data not shown).
Figure 2. S365 immunoprecipitation of rSERT protein. HeLa cells were transfected with rSERT, hSERT, or pBluescript SKII (vector) DNAs, metabolically labeled, and immunoprecipitated with either $\$ 365$ antisera, preimmune sera, or S365 antisera preincubated with S365 peptide $(10 \mu \mathrm{M})$ as described in Materials and Methods. Each lane derives from immunoprecipitation of extracts from $5 \times 10^{5} \mathrm{HeLa}$ cells. S365 antibody immunoprecipitates a major $61 \mathrm{kDa}$ species from both rat and human SERT-transfected cells absent from vector-transfected cells or after immunoprecipitation with preimmune or peptide-blocked antisera. S365 antibody also fails to recognize the homologous epitope in hNET (data not shown). The numbers to the left of the blot indicate the positions of molecular mass markers in kilodaltons electrophoresed in parallel. 
A

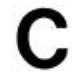

\section{Stds (kDa)}
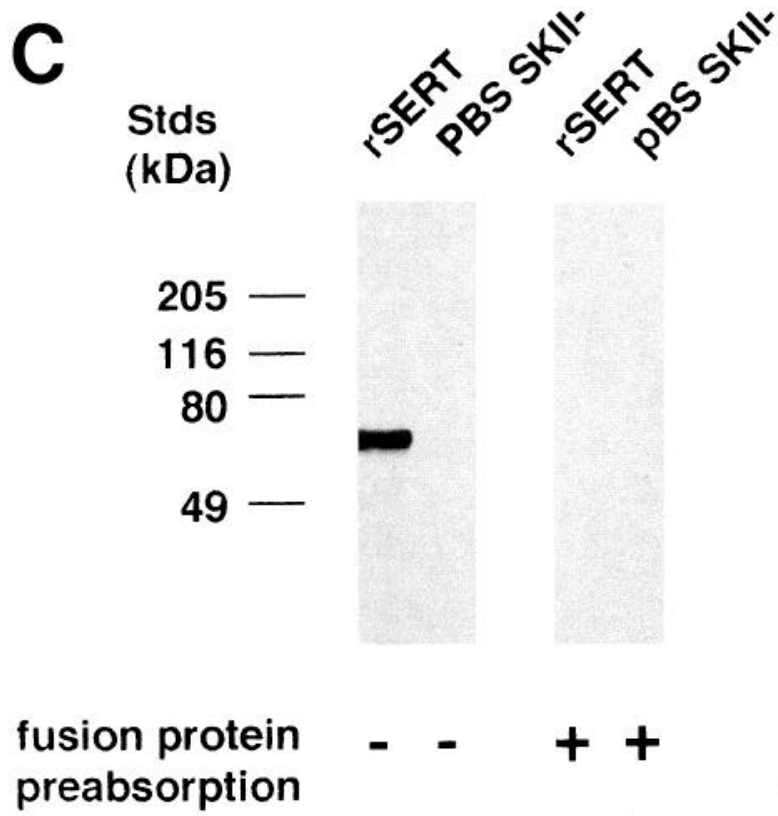

B

Stds (kDa)

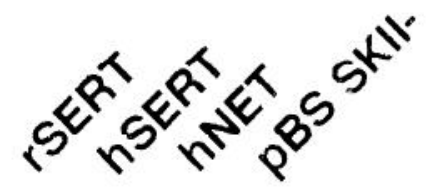

205

116

80

49
D

Stds
$(\mathrm{kDa})$
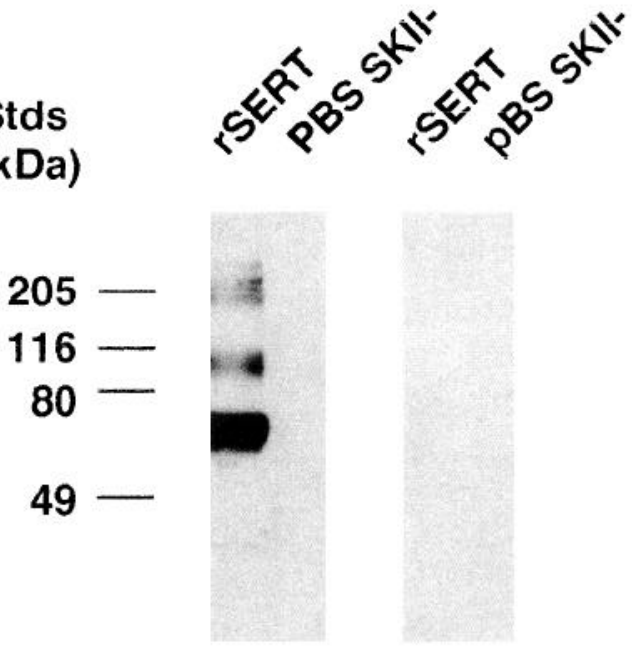

\section{fusion protein preabsorption}

Figure 3. Characterization of SERT fusion protein antibody CT-2 by immunoblot. A, Specificity of CT-2 immunoreactivity for SERT sequences. SDS-PAGE was performed witn purified glutathione-S-transferase (GST, $100 \mathrm{ng}$ ), total $E$. coli lysate from GST transformants [BL21(GST), $16 \mu \mathrm{g}$ ], or purified SERT fusion protein (GST-CT f.p., $100 \mathrm{ng}$ ), blotted and probed with CT-2 antibody $(1 \mu \mathrm{g} / \mathrm{ml})$ as described in Materials and Methods. The affinity-purified anti-SERT antibody recognized the fusion protein, but not the GST or the bacterial components. $B$, Detection of SERT expression in transfected HeLa cells. SDS-PAGE and immunoblot were performed as described in $A$, using solubilized membranes from $5 \mu \mathrm{g}$ of rSERT-transfected cells, $15 \mu \mathrm{g}$ of hSERT-transfected cells, $15 \mu \mathrm{g}$ of hNET-transfected cells, or $15 \mu \mathrm{g}$ of vector (PBSKII)-transfected cells. CT-2 antibody recognizes a major $61 \mathrm{kDa}$ protein in cells transfected with both rat and human SERT cDNAs but not in cells transfected with hNET cDNA. $C$, Extracts of rSERT cDNA- or vector-transfected HeLa cells $(5 \mu \mathrm{g}$ protein for each) were subjected to SDS-PAGE and immunoblotted with affinity-purified CT-2 antibody $(1 \mu \mathrm{g} / \mathrm{ml})$ with or without preincubation with purified SERT fusion protein $(100 \mu \mathrm{g} / \mathrm{ml}) . D, \mathrm{Longer}$ exposure of experiment presented in $A$ to emphasize additional SERT species detected by CT-2 antibody. Antibody recognition of all SERT species (61, 90 , and $200 \mathrm{kDa}$ ) was abolished by fusion protein preincubation. The numbers to the left of each blot indicate the positions of molecular mass markers in kilodaltons electrophoresed in parallel.

\section{Glycosylation state of endogenous and transfected rSERT} proteins

The multiple SERT proteins evident in transiently transfected HeLa cells and the disparate mobilities of endogenous brain and platelet SERT proteins prompted us to examine the presence and extent of SERT N-linked glycosylation. Metabolic labeling of transfected HeLa cells in the presence or absence of the glycosylation inhibitor tunicamycin (Fig. $5 A$ ) followed by SERT immunoprecipitation with $\mathrm{S} 365$ antibody revealed an increased mobility of SERT protein by approximately $5 \mathrm{kDa}$. To demon- 
A

\section{Stds (kDa)}

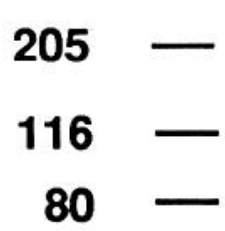

49

\section{Stds (kDa)}

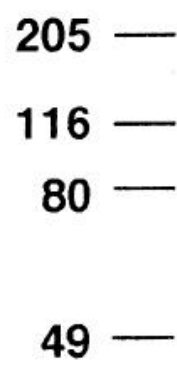

\section{fusion protein preabsoption}

Figure 4. Endogenous expression of SERT proteins. A, Brain and peripheral SERT expression. Extracts from tissue membranes $(50 \mu \mathrm{g})$ were subjected to SDS-PAGE and immunoblotted with CT-2 antibody $(1 \mu \mathrm{g} / \mathrm{ml})$ as described in Materials and Methods. The blot presented was exposed so as to reveal the species present in lung as well as in brain and platelet. $B$, Specificity of endogenous SERT detection by CT-2 antibody. Brain membrane extracts $(50 \mu \mathrm{g})$ were electrophoresed and blotted as in $A$ using either CT-2 antibody or CT-2 antibody preincubated with SERT fusion $(100 \mu \mathrm{g} / \mathrm{ml})$. CT-2-immunoreactive species in midbrain and cortex were absent from incubations conducted with fusion protein-absorbed antibody. The numbers to the left of each blot indicate the positions of molecular mass markers in kilodaltons electrophoresed in parallel. strate the presence of SERT glycosylation directly, membranes from SERT-transfected HeLa cells were digested with PNGase F prior to performing immunoblots with CT-2 fusion protein antibody. As with immunoprecipitations, the major species at 61 $\mathrm{kDa}$ shifted to an apparent molecular mass of $56 \mathrm{kDa}$ (Fig. $5 B$ ). In the data presented, blots were exposed to allow for the detection of the two more slowly migrating SERT species before and after PNGase F treatment. Whereas the most slowly migrating species at $200 \mathrm{kDa}$ failed to exhibit an appreciable mobility shift, the $90 \mathrm{kDa}$ form disappeared, presumably shifting to the $56 \mathrm{kDa}$ form. Thus, the lower molecular mass SERTs differentially accumulated in transfected HeLa cells appears to be due to different levels of N-linked glycosylation. Like HeLaexpressed SERTs, endogenous rat brain and platelet SERTs exhibited altered mobilities after PNGase F digestion, consistent with the presence of N-linked glycosylation (Fig. 5B). Although brain and platelet SERTs exhibit distinct mobilities by SDSPAGE prior to PNGAse F digestion or in mock digestions conducted in the absence of glycosidase, both proteins migrate equivalently at $60 \mathrm{kDa}$ following PNGase $\mathrm{F}$ treatment. Thus differential N-linked glycosylation also appears to generate distinct CNS and peripheral SERT subunits.

The $200 \mathrm{kDa}$ band present in transfected cells did not reveal an appreciable shift in relative molecular mass in our gel system. The $200 \mathrm{kDa}$ SERT form may represent a transporter aggregate. Prolonged incubations at elevated temperatures often resulted in the appearance of higher $M_{r}$ species (see Fig. $5 B$, platelet samples treated with PNGase F) and/or a loss of immunoreactivity. The loss of immunoreactivity of the $94 \mathrm{kDa}$ platelet species in mock digestions $\left(37^{\circ} \mathrm{C}, 4 \mathrm{hr}\right.$, no enzyme) was also observed in a repeat of this experiment and paralleled by an increase in aggregated SERT. Thus deglycosylated SERT monomers may have less of a tendency to nonspecifically aggregate, or glycosylation may be involved in multimerization. Interestingly, brain and platelet SERTs lacking $\mathrm{N}$-linked glycosylation migrate consistently slower (by $\sim 2 \mathrm{kDa}$ ) than do deglycosylated SERTs derived from transfected HeLa cells. The source of this difference in mobility remains to be elucidated.

\section{Immunocytochemical detection of rat and human brain SERT}

Since the CT-2 antibody specifically detected endogenous SERT proteins by immunoblot analysis, we explored its utility for visualizing the cellular localization of the transporter in situ. Immunocytochemistry performed on serial coronal sections of the entire rat brain using CT- 2 antibody revealed intense staining of neurons in the brainstem raphe nuclei. As shown in Figure 6A$C$, neurons of the dorsal raphe in both the lateral and medial subdivisions exhibit intense SERT immunoreactivity. At this level, neurons of the raphe pontine subdivision (B9) were also highly stained (Fig. 6D). The somatic staining filled the cytoplasm around unstained nuclei and also extended into dendritic elements. The neuropil SERT immunoreactivity was also dense and appeared comprised of puncta and varicose fibers. As is evident from Figure $6 A$, somatic staining was highly restricted with little or no immunoreactivity in perikarya outside of the raphe complex. Importantly, neurons of the locus ceruleus and substantia nigra that express homologous NETs and DATs, respectively, were devoid of staining although the neuropil of both areas were densely packed with SERT-immunoreactive fibers. We could detect no SERT-immunoreactive cells with the morphology of glia in any of our sections.

To validate the specificity of SERT immunoreactivity, adja- 
B

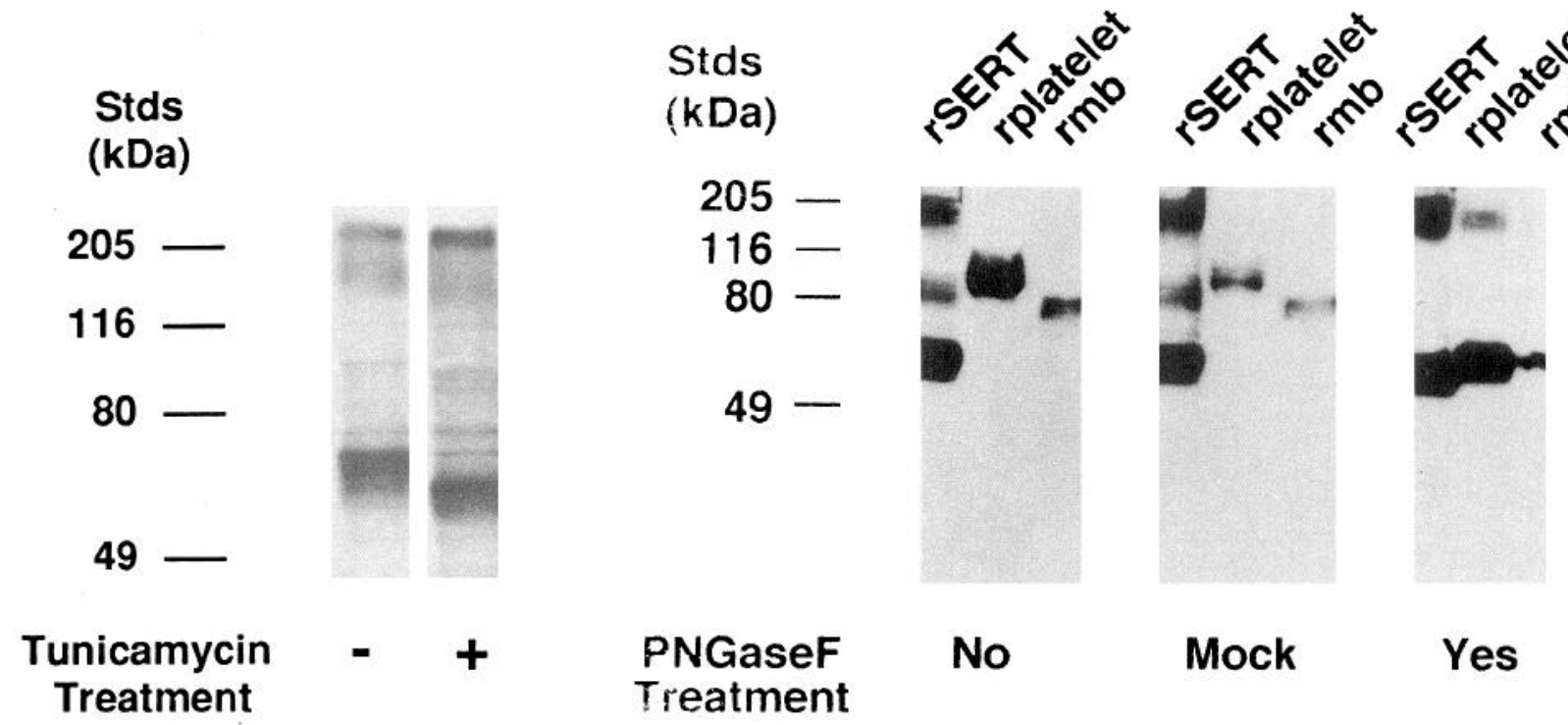

Figure 5. Analysis of rSERT N-linked glycosylation. A, Synthesis of rSERT in transfected HeLa cells in the presence or absence of tunicamycin. HeLa cells were transfected with rSERT cDNA, metabolically labeled with ${ }^{35}$ S-methionine and cysteine, and immunoprecipitated with S365 antibody as described in Materials and Methods. The major rSERT species detected at $61 \mathrm{kDa}$ from untreated cells shifts in mobility to $56 \mathrm{kDa}$ in cells treated with tunicamycin. $B$, Enzymatic deglycosylation of endogenous and transfected rSERT. Membranes from rSERT-transfected HeLa cells (from $25 \mu \mathrm{g}$ of cell homogenates, $5 \mu \mathrm{g}$ loaded), brain $(50 \mu \mathrm{g}$ ), and platelets $(50 \mu \mathrm{g})$ were treated with PNGase F to remove N-linked oligosaccharides as described in Materials and Methods. Samples were subjected to SDS-PAGE and immunoblotted with CT-2 antibody. Exposures were developed to visualize multiple SERT species in HeLa cells. Treatment with PNGase F increased the mobility of both transfected and endogenous SERTs. Both platelet and brain SERTs exhibit a $58 \mathrm{kDa}$ relative molecular mass after PNGase F digestion, whereas the transfected rSERT protein migrates as a $56 \mathrm{kDa}$ species. Treatment of platelet membranes with PNGase F resulted in the appearance of SERTs at $\sim 200 \mathrm{kDa}$, presumed to be a nonspecific aggregate. An aggregate was also present after mock treatments; however, in the experiment shown, this form resided at the interface of the stacking and resolving gel and is not shown.

cent sections were incubated with either affinity-purified CT-2 antibody, CT-2 antibody preabsorbed with SERT fusion protein $(100 \mu \mathrm{g} / \mathrm{ml})$, or without primary antibody. As shown in Figure $7, A$ and $B$, CT-2 staining is abolished by fusion protein preincubation. A similar absence of immunoreactivity was evident in CT-2 antibody-free incubations (data not shown). Adjacent sections incubated with anti-5HT antibody (Fig. $7 \mathrm{C}$ ) labeled the same medial, dorsal, and lateral subdivisions of the dorsal raphe complex detected by CT- 2 antibody, consistent with the conclusion that SERT-immunoreactive neurons are serotonergic.

In addition to cell body staining, SERT-immunoreactive fibers were observed throughout the rodent brain, particularly evident in forebrain regions known to receive a prominent serotonergic innervation, such as the hypothalamus, substantia nigra, hippocampus, amygdala, and cortex. In Figure $8 B$ and $C$, SERTimmunoreactive fibers can be seen to course throughout the rat hippocampus with highest density observed in molecular and polymorphic layers. The highest concentration of SERT-immunoreactive fibers in the hippocampal formation was observed in the molecular and polymorphic layers of the CA3 region, with reduced density in CA1 dendritic fields. The cerebellum contained few CT-2-positive fibers; particularly noticeable were a small population of highly varicose fibers terminating in rosettes in the granular layer of the flocculonodular lobe (data not shown). Like somatic staining, SERT fiber staining was eliminated by preincubation of CT-2 antibody with SERT fusion protein (data not shown). The visualization of SERT-immunoreactive fibers was also diminished in sections prepared with glutaraldehyde-containing fixative. However, $0.15-0.3 \%$ glutar- aldehyde provided significantly enhanced detection of immunoreactivity in cell bodies, apparently through a reduction of fiber staining in the surrounding neuropil.

Since CT-2 antibody recognized hSERT as well as rSERT in transfected cells and native tissues, we examined the ability of the antibody to stain serotonergic neurons and fibers in selected post-mortem human brain sections. As in the rat, the raphe nuclei showed dense immunoreactivity associated with cell bodies and neuropil (Fig. 9A,B). Neurons in the locus ceruleus and substantia nigra did not exhibit SERT immunoreactivity, although varicose axons were widely distributed throughout the mesopontine tegmentum as well as in entorhinal cortex (Fig. 9C,D). Glia appeared unstained. Control sections in which primary antibody was omitted showed no significant staining, although neuromelanin content of catecholamine neurons rendered them distinctly visible.

\section{Discussion}

Despite the importance of SERTs in the clearance of synaptic 5HT, SERT proteins have been only incompletely characterized. The availability of cloned rat (Blakely et al., 1991a; Hoffman et al., 1991), human (Lesch et al., 1993b,c; Ramamoorthy et al., 1993), and mouse (Chang et al., 1994) SERT cDNAs permitted the generation of sequence-specific antibodies to identify and localize SERT proteins in transfected cells and native tissues. SERTs are members of the $\mathrm{Na}^{+} / \mathrm{Cl}^{-}$cotransporter gene family and are most closely related to cocaine-sensitive NETs and DATs (Amara and Kuhra, 1993; Rudnick and Clark, 1993). However, these biogenic amine transporters exhibit substantial sequence 

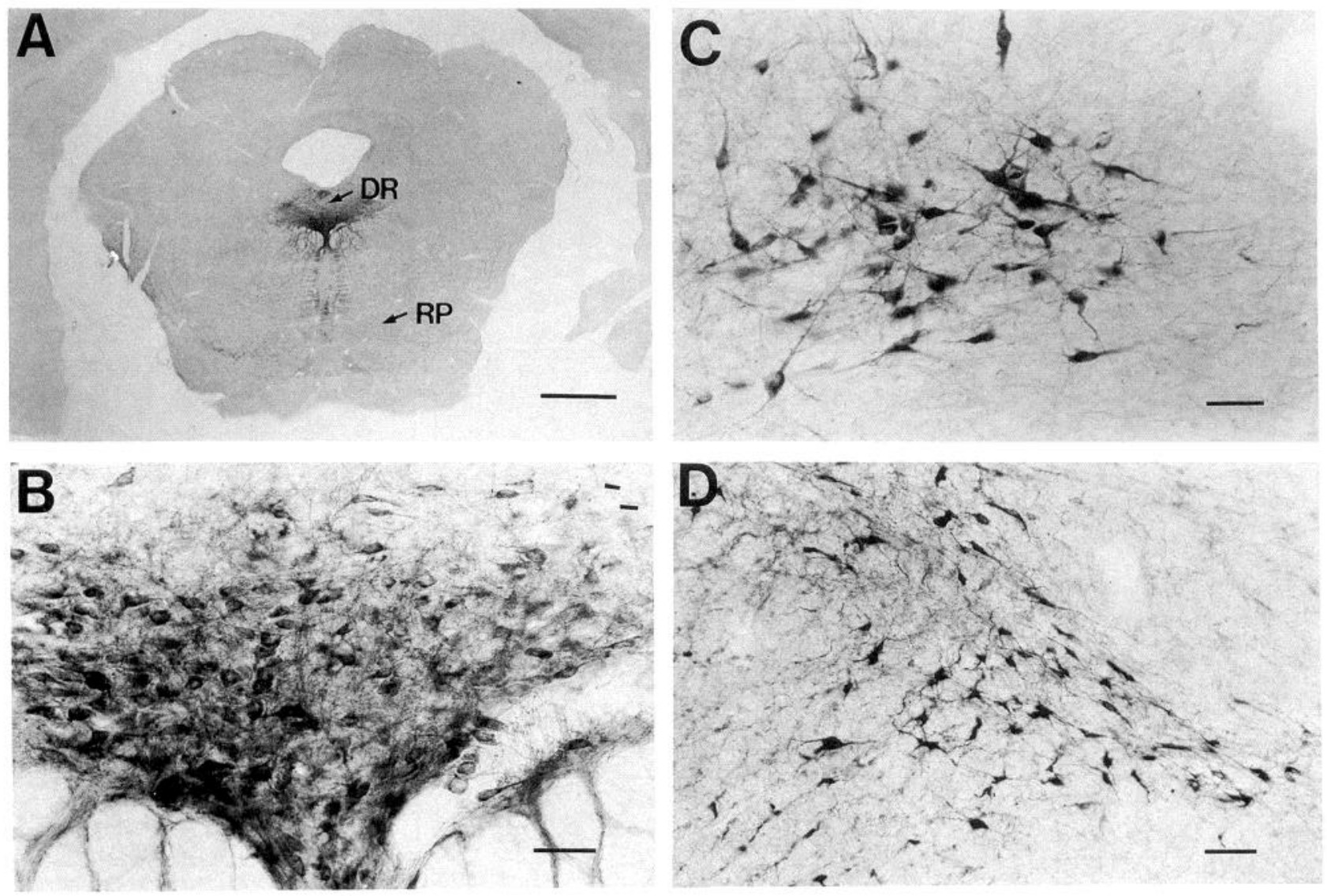

Figure 6. SERT-like immunoreactivity in the rat midbrain. Brain sections $(40 \mu \mathrm{m})$ were prepared from formaldehyde $(4 \%) / g l u t a r a l d e h y d e ~(0.3 \%)-$ perfused rats and stained with affinity-purified CT-2 antibody $(0.5 \mu \mathrm{g} / \mathrm{ml})$ as described in Materials and Methods. A, A coronal section through the rat midbrain displays intense SERT-like immunoreactivity restricted to midline neurons ventral to the third ventricle. The section shown is taken at the level of the dorsal raphe complex. B. Higher magnification of SERT-like-immunoreactive neurons in the median subnucleus of the dorsal raphe complex. $C$, Higher magnification of SERT-like-immunoreactive neurons in a lateral subnucleus of the dorsal raphe complex. $D$, SERT-likeimmunoreactive neurons in the nucleus raphe pontis. These neurons are ventral and lateral to the dorsal raphe groups depicted in $B$ and $C$. Scale bars: $A, 1000 \mu \mathrm{m} ; B-D, 50 \mu \mathrm{m}$.

divergence in regions between putative TMDs as well as in the predicted cytoplasmic $\mathrm{NH}_{2}$ - and $\mathrm{COOH}$-termini. We utilized two of these regions that are highly divergent among $\mathrm{Na}^{+} / \mathrm{Cl}^{-}$cotransporters, but highly conserved among SERT species variants, to prepare SERT-specific antibodies. The equivalent positions to the S365 and CT-2 epitopes in hNET exhibit only $14 \%$ and $29 \%$ identity with the comparable SERT sequences, respectively, and are further divergent with other members of the $\mathrm{Na}^{+} / \mathrm{Cl}^{-}$cotransporter gene family. Thus, this strategy has the potential for specific recognition of SERT proteins across multiple species.

\section{SERT antibody specificity analyzed in transfected cells}

To determine the specificity of SERT antipeptide and fusion protein antibodies, we transiently expressed rat or human SERT cDNAs in vaccinia-T7-infected HeLa cells. SERTs expressed in this manner transported 5HT with high affinity in an $\mathrm{Na}^{+}-$and $\mathrm{Cl}^{-}$- dependent manner, and are blocked by SERT-selective antagonists including paroxetine and citalopram (Blakely et al., 1991a; Hoffman et al., 1991; Ramamoorthy et al., 1993). S365 antisera specifically immunoprecipitated $61 \mathrm{kDa}$ proteins from both rSERT- and hSERT-transfected HeLa cells, as expected given the equivalent length of their predicted coding sequences; however, this antibody proved an unsuitable reagent for immunoblots of membranes prepared from the same cells. The S365 epitope could be sensitive to the denaturing conditions of SDSPAGE. This is a common characteristic of antipeptide antibodies, as evidenced in immunologic characterization of DAT (Vaughn et al., 1993) and NET (Melikian et al., 1994) proteins. However, when overexpressed in Sf9 cells, SERTs can be immunoblotted with the S365 antibody (Tate and Blakely, 1994). The level of functional expression in the baculovirus expression system is approximately fourfold greater than that obtained with SERT expression in HeLa cells (Blakely et al., 1993), and, in side by side comparisons, detection of the insect cell-expressed SERT with CT-2 serum is achieved with significantly greater dilutions of antisera compared with the S365 preparation (Tate and Blakely, 1994). These data indicate that the problem in use of the S365 antibody for immunoblotting lies with limited sensitivity (titer, affinity) rather than epitope availability. Given the predicted external location and proven antigenicity of this epitope, higher-affinity antibodies directed at this region may prove useful for SERT topology and membrane insertion analysis. The CT-2 antibody, directed at the rSERT COOH-terminus, represents a more useful reagent under a wide range of conditions for both heterologously expressed and endogenous SERTs. Thus, in both immunoprecipitation and immunoblot experiments with CT-2 antibody, a major $61 \mathrm{kDa}$ species is evident and absent from cells transfected with homologous transporter plasmids 

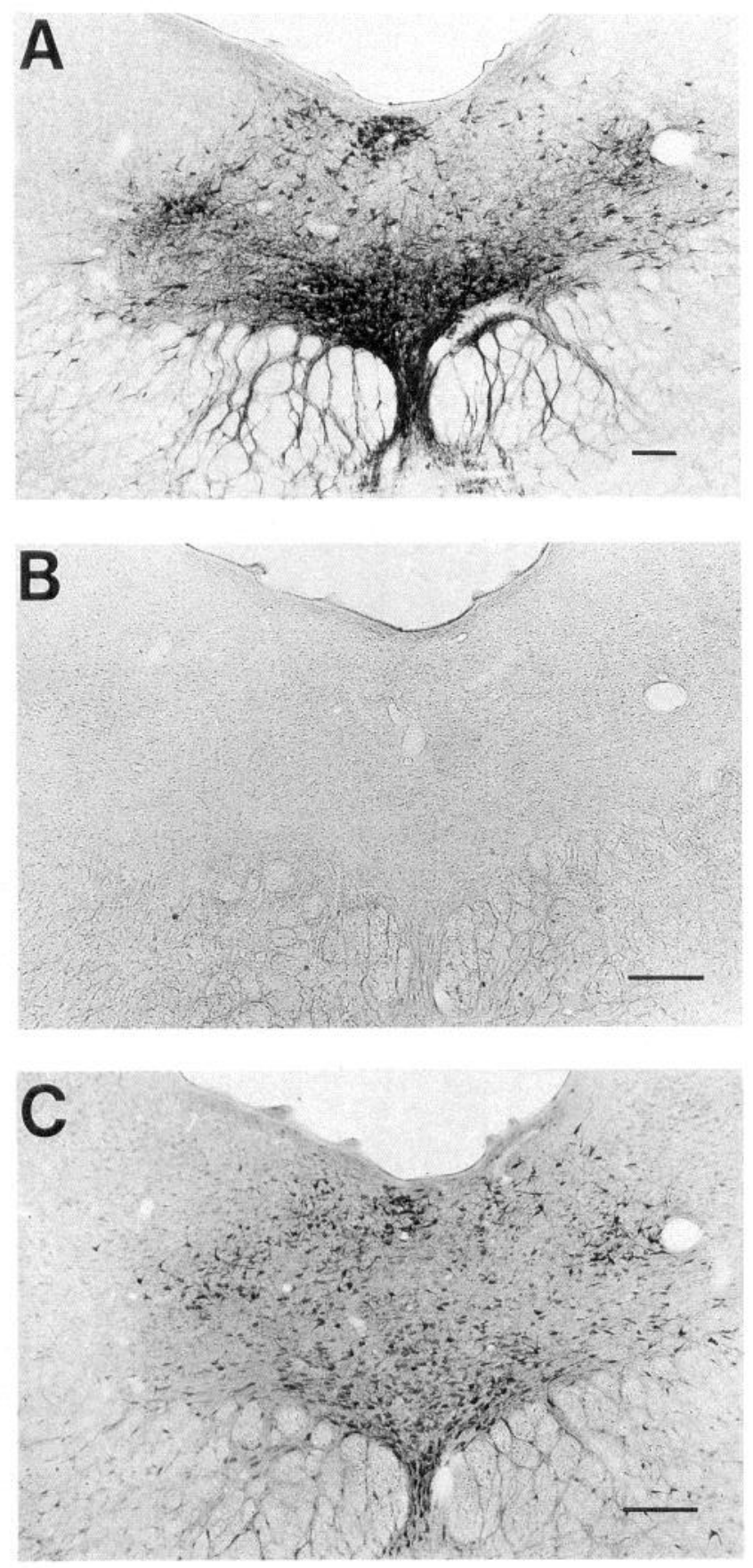

Figure 7. Specificity of SERT-like immunoreactivity. Adjacent rat brain sections $(40 \mu \mathrm{m})$ were prepared from formaldehyde $(4 \%) /$ glutaraldehyde $(0.3 \%)$-perfused rats and stained with $0.5 \mu \mathrm{g} / \mathrm{ml}$ affinity-purified CT-2 antibody $(A)$, CT-2 antibody preabsorbed with $100 \mu \mathrm{g} / \mathrm{ml}$ SERT fusion protein $(B)$, or 1:20,000 anti-5HT antibody $(C)$ as described in Materials and Methods. Note that all three subdivisions (dorsal, medial, lateral) of the dorsal raphe complex are stained with either CT-2 or anti-5HT antibody. With the conditions utilized for this experiment, fiber staining is more evident with the CT-2 antibody (particularly evident in the medial subnucleus) than with the 5HT antibody. Staining with CT-2 antibody is completely abolished with fusion protein preincubation. Scale bars: $100 \mu \mathrm{m}$.
(NET, e.g., Fig. 3; DAT, data not shown) or the plasmid vector alone. Interestingly, epitope-tagged SERTs bearing additional sequences on the rSERT COOH-terminus cannot be recognized by CT-2 antibodies on immunoblots (Tate and Blakely, 1994), suggesting that this antibody's main recognition site is positioned very near SERT's most COOH-terminal amino acids.

\section{SERT protein from brain and peripheral tissues}

In CNS, raphe nuclei express high levels of SERT mRNA (Blakely et al., 199.1a; Fujita et al., 1993; Austin et al., 1994). In addition, SERT activity has been described in certain peripheral tissues, including platelets (Sneddon, 1973; Rudnick, 1977) and lung (Gillis, 1985). The ability of SERT CT-2 antibody to detect SERT proteins on immunoblots allowed us to characterize the pattern of SERT protein expression in native membranes. Immunoblots with CT-2 antibody demonstrate the presence of single immunoreactive bands in both rat brain and peripheral tissues in a pattern consistent with predicted regional abundance. Thus, SERT proteins were evident in midbrain and cerebral cortex, but not cerebellum, which receives only a sparse serotonergic innervation (Steinsbusch, 1984; Takeuchi, 1988). SERT immunoreactivity in midbrain is greater than that found in cortex, paralleling the greater relative abundance observed for midbrain SERT antagonist-binding sites (De Souza and Kuyatt, 1987; Hrdina et al., 1989). The high level of SERT protein observed in platelets is consistent with the enrichment of 5HT transporter sites revealed by radioligand binding (Plenge and Mellerup, 1991). The low abundance of SERT-immunoreactive protein in the lung seems at odds with endogenous expression by pulmonary endothelial cells (Lee et al., 1986); alternatively, it may represent expression by the small number of 5HT-immunoreactive neuroepithelial bodies lining the airway mucosa (Youngson et al., 1993).

Interestingly, SDS-PAGE mobility of SERTs from rat platelet $(94 \mathrm{kDa})$ and pulmonary $(80 \mathrm{kDa})$ membranes differs significantly from that exhibited by rat brain SERTs ( $76 \mathrm{kDa})$. SERT protein coding sequences inferred from rat brain and basophilic leukemia cell (RBL) cDNAs are identical (Blakely et al., 1991a; Hoffman et al., 1991). Similarly, identical primary amino sequences have been predicted for human placental, brain, and platelet SERTs (Lesch et al., 1993b,c; Ramamoorthy et al., 1993). These data, along with the presence of a single SERT genomic locus in human (Ramamoorthy et al., 1993) and mouse (Gregor et al., 1993), suggested to us that differential post-translational modifications underlie the differences in size of brain and peripheral SERTs. Deglycosylation experiments verified that the distinct electrophoretic mobility of endogenous SERTs is due to differential N-glycosylation. Multiple mobilities were also observed for SERTs in transfected HeLa cells and, like NETs expressed in transfected LLC-PK, cells, appear to reflect sequential stages of transporter glycosylation (Melikian et al., 1994). The functional role of differential N-linked glycosylation of brain and platelet SERTs is presently unclear. CNS DATs have also been shown to exhibit endogenous region-specific glycosylation differences (Lew et al., 1992), although no functional consequences of these differences are known. Glycosylation plays a role in receptor and transporter assembly and trafficking (Rands et al., 1990; Asano et al., 1993; Collier et al., 1993), and in some cases contributes to functional properties (Boege et al., 1988; Leconte et al., 1992). Recent studies of rSERT point mutants lacking one or both $\mathrm{N}$-glycosylation sites indicate a reduction in SERT antagonist $B_{\max }$, but not $K_{D}$ (Tate and Blakely, 

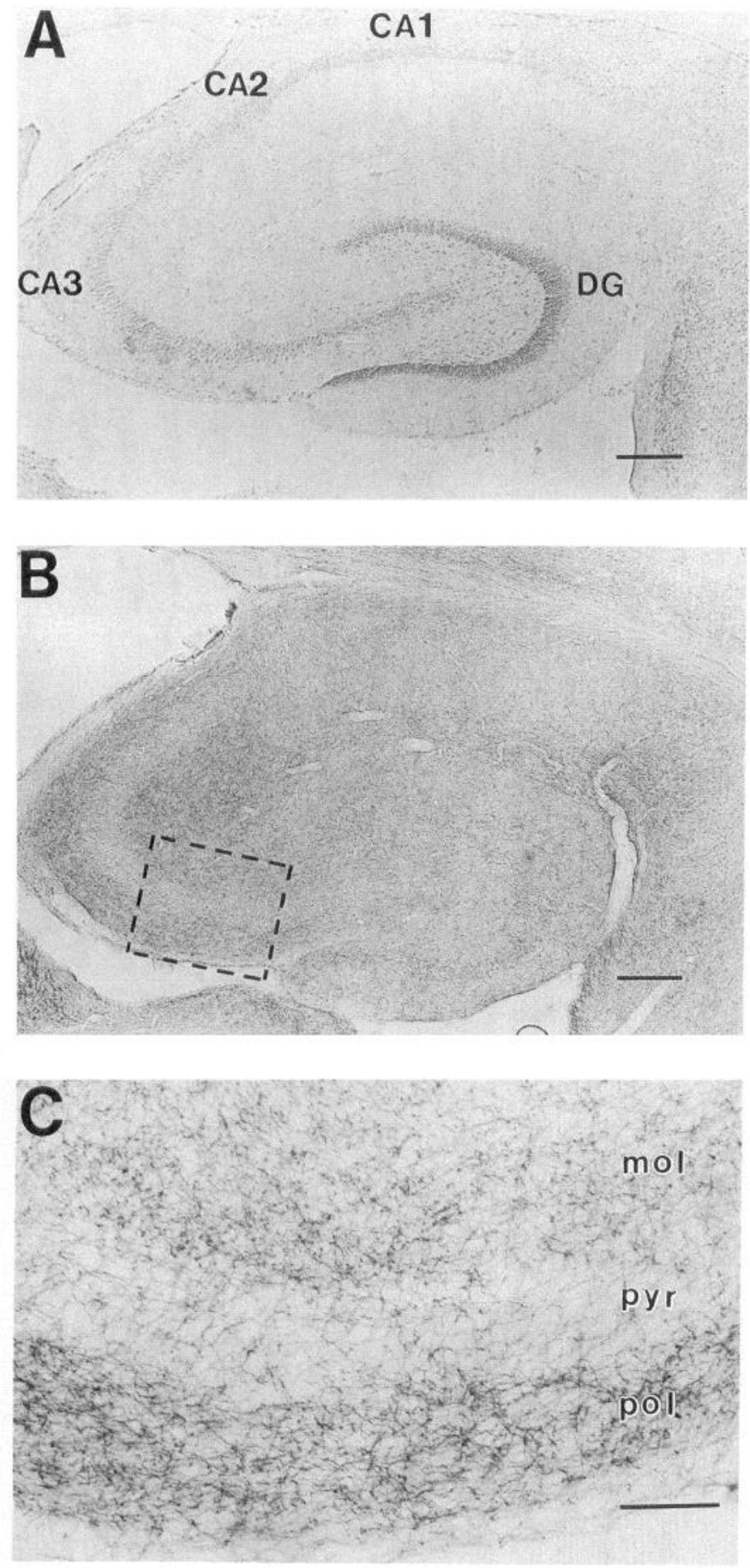

Figure 8. SERT-like-immunoreactive fiber staining in the rat hippocampal formation. Brain sections $(40 \mu \mathrm{m})$ were prepared from formaldehyde (4\%)-perfused rats and stained with affinity-purified CT-2 antibody $(0.5 \mu \mathrm{g} / \mathrm{ml})$ as described in Materials and Methods. A. Nissl stain of a horizontal section revealing the localization of neurons in the granule layer of the dentate gyrus $(D G)$ and pyramidal neurons (CAI-CA3) of the hippocampus. $B$, SERT-like-immunoreactive fibers concentrated in the polymorphic and molecular layers of the hippocampus. Note the high density of fibers in the CA3 region. $C$, High-power bright-field micrograph of CA3 region shown in the box of $B$. Note the appearance of varicose enlargements on individual fibers. Scale bars: $A$ and $B, 250$ $\mu \mathrm{m} ; C, 100 \mu \mathrm{m}$.
1994). These findings suggest that the differences in platelet and brain SERT mobility may be inconsequential for 5HT or SERT antagonist recognition, but rather may influence transporter biosynthetic efficiency in these distinct cellular contexts. A small $(2 \mathrm{kDa})$ but consistent difference in mobility exists between $\mathrm{N}$-deglycosylated SERTs derived from endogenous sources or transfected cells. These data suggest the existence of additional post-translational modifications of the endogenous SERT protein absent from SERT-transfected HeLa cells. Candidate SERT modifications, including O-linked glycosylation, sulfation, acylation, and/or phosphorylation, are presently under evaluation.

Antidepressant-binding glycoproteins from rat brain and human platelets have been partially purified (Biessen et al., 1990; Graham et al., 1992; Launay et al., 1992). The size of endogenous rat brain SERTs detected with CT-2 antibody agrees well with the size of a citalopram-binding protein $(73 \mathrm{kDa})$ partially purified from rat brain (Graham et al., 1992), supporting the hypothesis that a single protein comprises both the transport mechanism as well as SERT antidepressant recognition sites (Blakely et al., 1991a; Hoffman et al., 1991). However, the apparent $M_{r}$ of antidepressant-binding proteins partially purified from human platelets (78 kDa, Biessen et al., 1990; $68 \mathrm{kDa}$, Launay et al., 1992) is lower than what we obtained in direct platelet immunoblots. Possibly, these differences reflect different mass standards used for SDS-PAGE. In addition, we have noted that human platelet SERTs are susceptible to significant proteolysis during membrane preparation. In this regard, partially truncated SERTs expressed in HeLa cells still transport 5HT and recognize antidepressants with high affinity (Blakely et al., 1993), and thus could persevere through affinity-based purification procedures even if partially degraded. Finally, the mass of the core SERT polypeptide $(68 \mathrm{kDa})$ calculated from cloned rat cDNAs is higher than that derived from deglycosylated SERTs $(56 \mathrm{kDa})$, but can easily be accounted for by the anomalous mobility of highly hydrophobic transporter proteins on SDS gels (Keynan et al., 1992; Melikian et al., 1994).

\section{SERT-like immunoreactivity in serotoninergic neurons and processes}

SERT-like-immunoreactive soma in the rat brain were found to be highly restricted to serotonergic raphe nuclei in a manner virtually identical to that observed for rSERT gene expression (Blakely et al., 1991a; Fujita et al, 1993). The regional localization of SERTs in brain has previously been inferred by radioligand autoradiography using SERT antagonists such as imipramine (Fuxe et al., 1983), citalopram (D'Amato et al., 1987a; Duncan et al., 1992), and paroxetine (De Souza et al., 1987; Hrdina et al., 1990; Chen et al., 1992). Although autoradiography has limited cellular resolution, SERT distribution inferred from these studies concurs with the localization of 5HT immunoreactivity (Steinbusch, 1984; Takeuchi, 1988). In our studies, SERT-immunoreactive fibers are prominent in the same brain structures that exhibit high-level SERT antagonist binding. Thus, the cerebellum, which receives only a sparse 5HT innervation and exhibits low-density ${ }^{3} \mathrm{H}$-antagonist binding, possesses only a few immunoreactive SERT fibers (and undetectable levels of SERT protein on immunoblots). Within the hippocampus proper, the $\mathrm{CA} 2-\mathrm{CA} 3$ region has been shown to display the highest level of ${ }^{3} \mathrm{H}$-paroxetine and ${ }^{3} \mathrm{H}$-citalopram binding (Hrdina et al., 1990; Duncan et al., 1992), and similarly this region possesses a greater density of SERT-immunoreactive terminals than does CAl or the dentate gyrus. The rat brain region with the greatest 

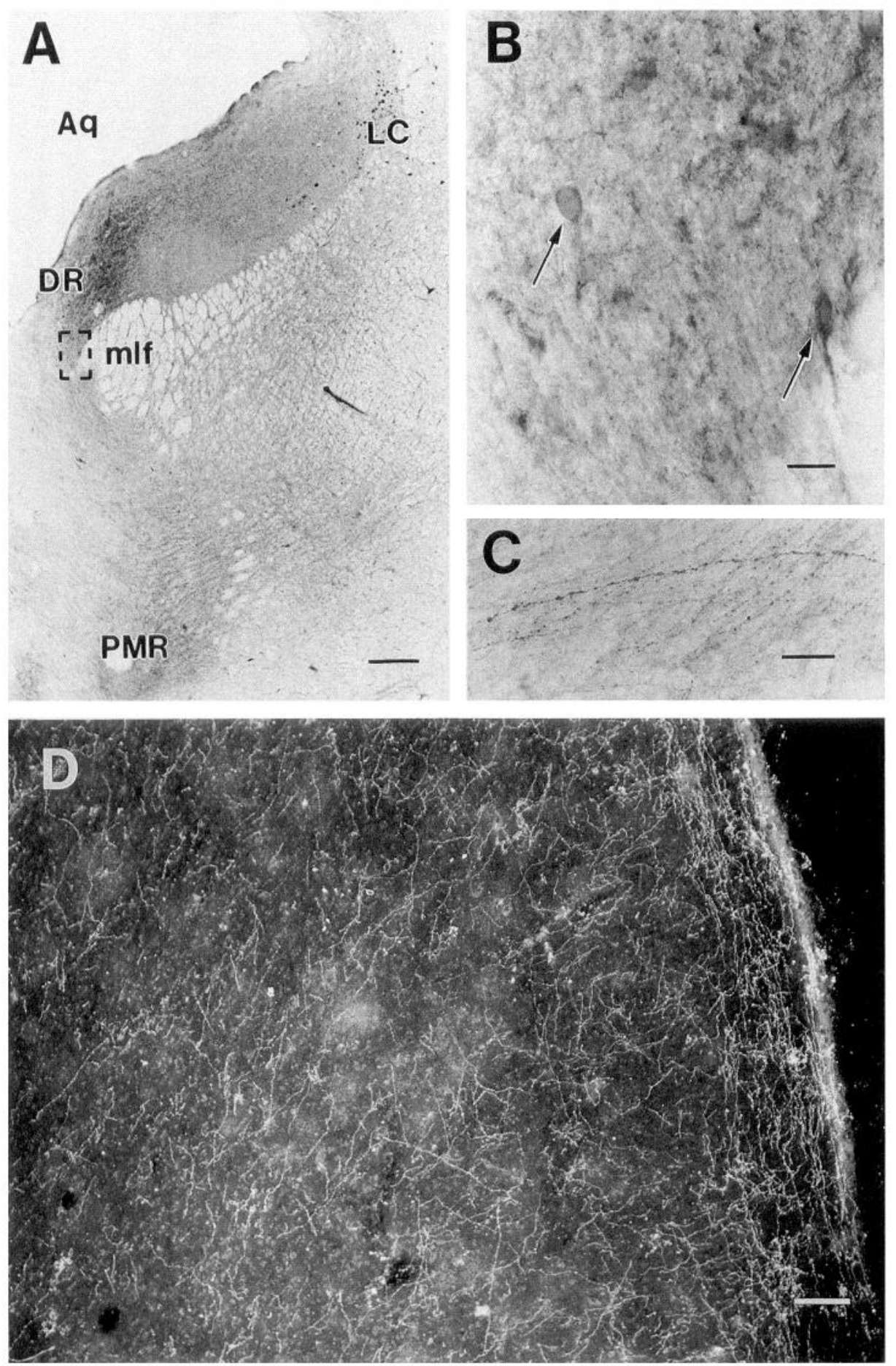

Figure 9. Immunocytochemical localization of SERT in human brain. Brains were fixed by immersion in cold 4\% paraformaldehyde in $0.1 \mathrm{M}$ sodium phosphate buffer, $\mathrm{pH} 7.2$, for $24-36 \mathrm{hr}$ prior to sectioning and staining with CT-2 antibody $(0.5 \mu \mathrm{g} / \mathrm{ml})$, as described in Materials and Methods. A, Bright-field photomicrograph of a coronal section through the rostral pons. Note the dense immunoreactivity in the dorsal raphe $(D R)$ and paramedian raphe $(P M R)$. Neurons in the locus ceruleus $(L C)$ are unstained but visible because of neuromelanin content. $B$, Higher magnification of the boxed area in $A$, showing examples of immunoreactive neuronal perikarya (arrows) embedded in the densely stained neuropil in the DR. $C$, Example of immunoreactive varicose fibers in the central gray. $D$, Dark-field photomicrograph of entorhinal cortex, demonstrating immunoreactive fibers scattered throughout the cortical mantle. The pial surface is on the right and the deep white matter is on the extreme left. Scale bars: $A, 500 \mu \mathrm{m} ; B$ and $D, 50$ $\mu \mathrm{m} ; C 15 \mu \mathrm{m}$. density of SERT antagonist-binding sites has been found to be the dorsal raphe itself (D'Amato et al., 1987; De Souza et al., 1987; Hrdina et al., 1990; Chen et al., 1992; Duncan et al., 1992). Consistent with these data, SERT-immunoreactive cell bodies of the dorsal raphe are surrounded by a dense network of SERT-immunoreactive processes. Indeed, we found that cell body staining was clearly apparent but difficult to demonstrate under standard (4\% paraformaldehyde) fixation conditions due to the densely stained neuropil. The addition of low concentrations of glutaraldehyde $(0.15-0.3 \%)$ diminished fiber staining and significantly improved cell soma visualization of SERT immunoreactivity.

SERT-like immunoreactivity was abolished by fusion protein preabsorption at concentrations that eliminated visualization of SERT bands detected by immunoblots. Specificity was further evident in an absence of cell body staining in brain regions densely populated with NE and DA neurons that synthesize homologous NET and DAT proteins. SERT-immunoreactive neurons and fibers were evident in both human as well as rat brain, consistent with the high homology of the CT- 2 epitope across 
species and with the ability of the antibody to immunoblot hSERT from transfected cells (Fig. 3B) and human brain and platelets (data not shown). Finally, parallel staining in adjacent sections with anti-5HT antiscra demonstrated a high correspondence in the cellular and axonal distribution of SERT and 5HT immunoreactivity. The SERT antibody may prove a superior reagent to 5HT-directed antibodies for the identification of serotonergic axons and terminals in circumstances, endogenous or induced, where reduced 5HT synthesis and/or storage may occur independently of structural alterations in neuronal processes (Takeuchi et al., 1988; Dewar et al., 1992).

SERT expression has been attributed to cultured and endogenous glial as well as neuronal elements (Kimelberg, 1986; Anderson et al., 1992). As with SERT localization by in situ hybridization, SERT distribution by immunocytochemistry appears to argue against a high level of endogenous glial SERT expression, if any, in the adult rat. Only a single SERT gene appears to be present in humans (Ramamoorthy et al., 1993) and mouse (Gregor et al., 1993); it remains possible that glial 5HT uptake arises from the cxpression of an additional SERT, generated by alternative splicing and lacking the CT-2 epitope, or that the CT-2 epitope is modified or masked in glia. Lesch and colleagues (Lesch et al., 1993a) have reported the presence of SERT mRNAs, using reverse transcription/polymerase chain reaction (RT-PCR) in regions associated with serotonergic terminals but not cell bodies. The clear ability of RT-PCR to amplify rare mRNAs of insufficient endogenous levels to contribute to functional protein pools (Chelly et al., 1989) suggests caution in attributing functional significance to these data. An alternative explanation for the in vitro glial findings is that SERTs may be expressed by glia early in CNS development but not in the adult, such that primary glial cultures derived from neonatal brain retain transport activity in vitro that eventually they lose in vivo. Finally, expression of 5HT uptake may be induced by culture conditions with little relevance to the pattern of expression in situ (Kimelberg et al., 1992).

In summary, we have achieved the first direct visualization of SERT proteins expressed in transfected and native membranes using SERT peptide and fusion protein-directed antibodies. SERT protein is distributed in a manner consistent with the known localization of 5HT uptake, SERT antagonist binding, and $5 \mathrm{HT}$ immunoreactivity. Differential $\mathrm{N}$-glycosylation gives rise to variant SERT proteins in the CNS and periphery. The similar size of endogenous SERT proteins to purified antidepressant-binding proteins, the ability of singlc cDNAs to induce antidepressant-sensitive 5HT uptake, and the correspondence of SERT anatomical distribution with ${ }^{3} \mathrm{H}$-antidepressant autoradiographic localization argue strongly that a single gene product comprises the functional unit of SERTs in vivo. Finally, the conservation of the SERT epitopes utilized for antibody production permits recognition of SERT proteins in both rodent and human preparations, providing an important opportunity to investigate alterations in SERT structure and expression in neurologic and psychiatric disorders.

\section{References}

Amara SG, Kuhar MJ (1993) Neurotransmitter transporters: recent progress. Annu Rev Neurosci 16:73-93.

Anderson EJ, McFarland D, Kimelberg HK (1992) Serotonin uptake by astrocytes in situ. Glia 6:154-158.

Asano T, Takata $\mathrm{K}$, Katagiri $\mathrm{H}$, Ishihara $\mathrm{H}$, Inukai $\mathrm{K}$, Anai $\mathrm{M}$, Hirann H, Yazaki Y, Oka Y (1993) The role of N-glycosylation in the tar- geting and stability of GLUT1 glucose transporter. FEBS Lett 324 : 258-261.

Austin MMC, Bradley CC, Mann JJ, Blakely RB (1994) Expression of serotonin transporter messenger RNA in the human brain. $\mathrm{J}$ Neurochem 62:2362-2367.

Azmitia EC, Marovitz WF (1980) In vitro hippocampal uptake of tritiated serotonin $\left({ }^{3} \mathrm{H}-5 \mathrm{HT}\right)$ : a morphological, biochemical, and pharmacological approach to specificity. J Histochem Cytochem 28:636644.

Balkovetz DF, Tiruppathi C, Leibach FH, Mahesh VB, Ganapathy V (1989) Evidence for an imipramine-sensitive serotonin transporter in human placental brush-border membranes. J Biol Chem 264:21952198.

Barker EL, Blakely RD (1994) Norepinephrine and serotonin transporters: molecular targets of antidepressant drugs. In: Psychopharmacology: the fourth generation of progress (Bloom FE, Kupfer D, eds), in press. New York: Raven.

Biessen EA, Horn AS, Robillard GT (1990) Partial purification of the 5-hydroxytryptophan-reuptake system from human blood platelets using a citalopram-derived affinity resin. Biochemistry 29:33493354 .

Björkland A, Nobin A, Stenevi U (1973) Effects of 5,6-dihydroxytryptamine on nerve terminal serotonin and serotonin uptake in the rat brain. Brain Res 53:117-127.

Blakely RD, Berson HE, Fremeau RT Jr, Caron MG, Peek MM, Prince HK, Bradley CC (1991a) Cloning and expression of a functional serotonin transporter from rat brain. Nature 354:66-70.

Blakely RD, Clark JA, Rudnick G, Amara SG (1991b) Vaccinia-T7 RNA polymerase expression system: evaluation for the expression cloning of plasma membrane transporters. Anal Biochem 194:302308.

Blakely RD, Moore KR, Qian Y (1993) Tails of serotonin and norepinephrine transporters: deletion and chimeras retain function. In: Molecular biology and function of carrier proteins (Reuss L, Russell JM, Jennings ML, eds), pp 283-300. New York: Rockefeller UP.

Boege F, Ward M, Jürss W, Hekman M, Helmreich EJM (1988) Role of glycosylation for $\beta 2$-adrenoceptor function in A431 cells. J Biol Chem 263:9040-9049.

Bruns D, Engert F, Lux HD (1993) A fast activating presynaptic reuptake current during serotonergic transmission in identified neurons of hirudo. Neuron 10:559-572.

Chang AS, Chang SM, Starnes DM, Schroeter S, Baumaan AL, Blakely $\mathrm{RD}$ (1994) Cloning and expression of the mouse serotonin transporter. Mol Brain Res, submitted.

Chelly J, Concordet J-P, Kaplan J-C, Kahn A (1989) Illegitimate transcription: transcription of any gene in any cell type. Proc Natl Acad Sci USA 86:2617-2621.

Chen H-T, Clark M, Goldman D (1992) Quantitative autoradiography of ${ }^{3} \mathrm{H}$-paroxetine hinding sites in rat hrain. J Pharmacol Toxicol Methods 27:209-216.

Chinaglia G, Landwehrmeyer B, Probst A, Palacios JM (1993) Serotonergic terminal transporters are differentially affected in Parkinson's disease and progressive supranuclear palsy: an autoradiographic study with $\left[{ }^{3} \mathrm{H}\right]$ citalopram. Neuroscience 54:691-699.

Collier E, Carpentier J-L, Beitz L, Caro HP, Taylor SI, Gorden P (1993) Specific glycosylation site mutations of the insulin receptor $\alpha$ subunit impair intracellular transport. Biochemistry 32:7818-7823.

D'Amato RJ, Largent BL, Snowman AM, Snyder SH (1987a) Selective labeling of serotonin uptake sites in rat brain by $\left[{ }^{3} \mathrm{H}\right]$ citalopram contrasted to labeling of multiple sites by $\left[{ }^{3} \mathrm{H}\right]$ imipramine. J Pharmacol Exp Ther 242:364-371.

D'Amato RJ, Zweig RM, Whitehouse PJ, Wenk GL, Singer HS, Mayeux R, Price DL, Snyder SH (1987b) Aminergic systems in Alzheimer's disease and Parkinson's disease. Ann Neurol 22:229-236.

Daoust M, Lhuintre JP, Ernouf D, Legrand E, Breton P, Boucly P (1991) Ethanol intake and ${ }^{3} \mathrm{H}$-serotonin uptake II: a study in alcoholic patients using platelets ${ }^{3} \mathrm{H}$-paroxetine binding. Life Sci 48:1977-1983.

Da Prada M, Cesura AM, Launay JM, Richards JG (1988) Platelets as a model for neuron? Experientia 44:115-126.

De Souza EB, Kuyatt BL (1987) Autoradiographic localization of ${ }^{3} \mathrm{H}-$ paroxetine-labeled serotonin uptake sites in rat brain. Synapse 1:488496.

Dewar KM, Grondin L, Carli M, Lima L, Reader TA (1992) $\left[{ }^{3} \mathrm{H}\right]$ paroxetine binding and serotonin content of rat cortical areas, hippocampus, neostriatum, ventral mesencephalic tegmentum, and 
midbrain raphe nuclei region following $p$-chlorophenylalanine and $p$-chloroamphetamine treatment. J Neurochem 58:250-257.

Duncan GE, Little KY, Kirkman JA, Kaldas RS, Stumpf WE, Breese GR (1992) Autoradiographic characterization of $\left[{ }^{3} \mathrm{H}\right]$ imipramine and $\left[{ }^{3} \mathrm{H}\right]$ citalopram binding in rat and human brain: species differences and relationships to serotonin innervation patterns. Brain Res 591: 181-197.

Ellis PM, Salmond C (1994) Is platelet imipramine binding reduced in depression? A meta-analysis. Biol Psychol, in press.

Fozard IR, ed (1989) Peripheral actions of 5-hydroxytryptamine. New York: Oxford UP.

Fuerst TS, Niles EG, Studier FW, Moss B (1986) Eukaryotic transientexpression system based on recombinant vaccinia virus that synthesizes bacteriophage T7 RNA polymerase. Proc Natl Acad Sci USA 83:8122-8126.

Fujita M, Shimada S, Maeno H, Nishimura T, Tohyama M (1993) Cellular localization of serotonin transporter mRNA in the rat brain. Neurosci Lett 162:59-62.

Fuller RW, Wong DT (1990) Serotonin uptake and serotonin uptake inhibition. Ann NY Acad Sci 600:68-78.

Fuxe K, Calza L, Benfenati F, Zini I, Agnati I.F (1983) Quantitative autoradiographic localization of $\left[{ }^{3} \mathrm{H}\right]$ imipramine binding sites in the brain of the rat: relationship to ascending 5-hydroxytryptamine neuron systems. Proc Natl Acad Sci USA 80:3836-3840.

Gillis CN (1985) Peripheral metabolism of serotonin. In: Serotonin and the cardiovascular system (Vanhoutte PM, ed), pp 27-36. New York: Raven.

Graham D, Esnaud H, Langer SZ (1992) Partial purification and characterization of the sodium-ion-coupled 5-hydroxytryptamine transporter of rat cerebral cortex. Biochem J 286:801-805.

Gregor P, Patel A, Shimada S, Lin CL, Rochelle JM, Kitayama S, Seldin MF, Uhl GR (1993) Murine serotonin transporter: sequence and localization to chromosome 11. Mamm Genome 4:283-284.

Harlow E, Lane D (1988) Antibodies: a laboratory manual. Cold Spring IIarbor, NY: Cold Spring IIarbor Laboratory.

Hoffman BJ, Mezey E, Brownstein MJ (1991) Cloning of a serotonin transporter affected by antidepressants. Science 254:579-580.

Hrdina PD, Foy B, Hepner A, Summers RJ (1990) Antidepressant binding sites in brain: autoradiographic comparison of $\left[{ }^{3} \mathrm{H}\right]$ paroxetine and $\left[{ }^{3} \mathrm{H}\right]$ imipramine localization and relationship to serotonin transporter. J Pharmacol Exp Ther 252:410-418.

Joyce JN, Shane A, Lexow N, Winokur A, Casanova MF, Kleinman JE (1993) Serotonin uptake sites and serotonin receptors are altered in the limbic system of schizophrenics. Neuropsychopharmacology $8: 315-336$.

Kaplan RD, Mann JJ (1982) Altered platelet serotonin uptake kinetics in schizophrenia and depression. Life Sci 31:583-588.

Keynan S, Suh Y-J, Kanner BI, Rudnick G (1992) Expression of a cloned $\gamma$-aminobutyric acid transporter in mammalian cells. Biochemistry 31:1974-1979.

Kimelberg HK (1986) Occurrence and functional significance of serotonin and catecholamine uptake by astrocytes. Biochem Pharmacol 35:2273-2281.

Kimelberg HK, Goderie SK, Conley PA, Higman S, Goldschmidt R, Amundson RH (1992) Uptake of $\left[{ }^{3} \mathrm{H}\right]$ serotonin and $\left[{ }^{3} \mathrm{H}\right]$ glutamate by primary astrocyte cultures. I. Effects of different sera and time in culture. Glia $6: 1-8$.

Kuhar MJ, Roth RH, Aghajanian GK (1972) Synaptosome from forebrains of rats with midbrain raphe lesions: selective reduction of serotonin uptake. J Pharmacol Exp Ther 181:36-45.

Laemmli UK (1970) Cleavage of structural proteins during the assembly of the head of bacteriophage T4. Nature 227:680-685.

Launay JM, Geoffroy C, Mutel V, Buckle M, Cesura A, Alouf JE, Da Prada M (1992) One-step purification of the serotonin transporter located at the human platelet plasma membrane. J Biol Chem 267: $11344-11351$.

LeConte I, Auzan C, Debant A, Rossi B, Clauser E (1992) N-linked oligosaccharide chains of the insulin receptor $\beta$ subunit are essential for transmembrane signaling. J Biol Chem 267:17415-17423.

Lee SL, Fanburg BL (1986) Serotonin uptake by bovine pulmonary artery endothelial cells in culture. I. Characterization. Am J Physiol 250:C761_C765.

Lesch KP, Aulakh CS, Wolozin BL, Tolliver TJ, Hill JL, Murphy DL (1993a) Regional brain expression of serotonin transporter mRNA and its regulation by reuptake inhibiting antidepressants. Mol Brain Res 17:31-35.

Lesch KP, Wolozin BL, Estler HC, Murphy DL, Diederer P (1993b) Isolation of a cDNA encoding the human brain serotonin transporter. J Neural Transm 91:67-73.

Lesch KP, Wolozin BL, Murphy DL, Riederer P (1993c) Primary structure of the human platelet serotonin uptake site: identity with the brain serotonin transporter. J Neurochem 60:2319-2322.

Levey AI, Kitt CA, Simonds WF, Price DL, Brann MR (1991) Identification and localization of muscarinic acetylcholine receptor proteins in brain with subtype-specific antibodies. J Neurosci 11:32183226.

Lew R, Patel A, Vaughan RA, Wilson A, Kuhar MJ (1992) Microheterogeneity of dopamine transporters in rat striatum and nucleus accumbens. Brain Res 584:266-271.

Marcusson JO, Ross SB (1990) Binding of some antidepressants to the 5-hydroxytryptamine transporter in brain and platelets. Psychopharmacology 102:145-155.

Melikian HE, McDonald JK, Gu H, Rudnick G, Moore KR, Blakely RD (1994) Human norepinephrine transporter: biosynthetic studies using a site-directed polyclonal antibody. J Biol Chem 269:1229012297.

Meltzer HY, Arora RC, Baber R, Tricou BJ (1981) Serotonin uptake in blood platelets of psychiatric patients. Arch Gen Psychiatry 38: $1322-1326$.

Nemeroff CB, Knight DL, Krishnan KRR, Slotkin TA, Bissette G, Melville ML, Blazer DG (1988) Marked reduction in the number of platelet tritiated imipramine binding sites in geriatric depression. Arch Gen Psychiatry 45:919-923.

O'Reilly CA, Reith MEA (1988) Uptake of [ $\left.{ }^{3} \mathrm{H}\right]$ serotonin into plasma membrane vesicles from mouse cerebral cortex. J Biol Chem 263: 6115-6121.

Owens MJ, Nemeroff CB (1994) The role of serotonin in the pathophysiology of depression: focus on the serotonin transporter. Clin Chem 40:288-295.

Pacholczyk T, Blakely RD, Amara SG (1991) Expression cloning of a cocaine and antidepressant-sensitive human noradrenaline transporter. Nature 350:350-354.

Paul SM, Rehavi M, Skolnick P, Ballenger JC, Goodwin FK (1981) Depressed patients have decreased binding of tritiated imipramine to platelet serotonin "transporter." Arch Gen Psychiatry 38:1315-1318.

Plenge P, Mellerup ET (1991) [ $\left.{ }^{3} \mathrm{H}\right]$ Citalopram binding to brain and platelet membranes of human and rat. J Neurochem 56:248-252.

Pristupa ZB, Wilson JM, Hoffman BJ, Kish SJ, Niznik HB (1994) Pharmacological heterogeneity of the cloned and native human dopamine transporter: disassociation of $\left[{ }^{3} \mathrm{H}\right]$ WIN 35,428 and $\left[{ }^{3} \mathrm{H}\right] \mathrm{GBR}$ 12,935 binding. Mol Pharmacol 45:125-135.

Raisman G, Cash R, Agid Y (1986) Parkinson's disease: decreased density of ${ }^{3} \mathrm{H}$-imipramine and ${ }^{3} \mathrm{H}$-paroxetine binding sites in putamen. Neurology 36:556-560.

Ramamoorthy S, Bauman AL, Moore KR, Han H, Yang-Feng T, Chang AS, Ganapathy V, Blakely RD (1993) Antidepressant- and cocainesensitive human serotonin transporter: molecular cloning, expression, and chromosomal localization. Proc Natl Acad Sci USA 90:25422546.

Rands E, Candelore MR, Cheung AH, Hill WS, Strader CD, Dixon RAF (1990) Mutational analysis of $\beta$-adrenergic receptor glycosylation. J Biol Chem 265:10759-10764.

Ross SB, Renyi AL (1967) Accumulation of tritiated 5-hydroxytryptamine in brain slices. Life Sci 6:1407-1415.

Rudnick G (1977) Active transport of 5-hydroxytryptamine by plasma membrane vesicles isolated from human blood platelets. J Biol Chem 252:2170-2174.

Rudnick G, Clark J (1993) From synapse to vesicle: the reuptake and storage of biogenic amine neurotransmitters. Biochim Biophys Acta 1144:249-263.

Saiki RK, Gekfand DH, Stoffel S, Scharf SJ, Horn GT, Mullis KB, Erlich HA (1988) Primer-directed enzymatic amplification of DNA with a thermostable DNA polymerase. Science 239:487-494.

Sanger F, Nicklen S, Coulson AR (1977) DNA sequencing with chainterminating inhibitors. Proc Natl Acad Sci USA 74:5463-5467.

Smith DB, Johnson KS (1988) Single-step purification of polypeptides in Escherichia coli as fusions with glutathione S-transferase. Gene 67:31-40. 
Sneddon JM (1973) Blood platelets as a model for monoamine-containing ncurons. Prog Neurobiol 1:153-198.

Stahl SM (1977) The human platelet: a diagnostic and research tool for the study of biogenic amines in psychiatric and neurologic disorders. Arch Gen Psychiatry 34:509-516.

Stanley M, Virgilio J, Gershon S (1982) Tritiated imipramine binding sites are decreased in the frontal cortex of suicides. Science 216: 1337-1339.

Steinbusch HWM (1984) Serotonin-immunoreactive neurons and their projections in the CNS. In: Handbook of chemical neuroanatomy, Vol 3, Classical transmitter receptors in the CNS, Pt II (Bjorklund A, Hokfelt T, Kuhar MJ, eds), pp 68-125. Amsterdam: Elsevier.
Takeuchi Y (1988) Distribution of serotonin neurons in the mammalian brain. In: Neuronal serotonin (Osborne NN, Hamon M, cds), pp 2556. New York: Wiley.

Tate GC, Blakely RD (1994) The effect of N-linked glycosylation for activity of the $\mathrm{Na}^{-}$and $\mathrm{Cl}^{-}$dependent serotonin transporter expressed using baculovirus in insect cells. $\mathbf{J}$ Biol Chem, in press.

Tuomisto J, Tukianen E (1976) Decreased uptake of 5-hydroxytryptamine in blood platelets from depressed patients. Nature 262:596-598

Vaughan RA, Uhl G, Kuhar MJ (1993) Recognition of dopamine transporters by antipeptide antibodies. Mol Cell Neurosci 4:209-215.

Youngson C, Nurse C, Yeger H, Cutz Z (1993) Oxygen sensing in airway chemoreceptors. Nature 365:153-155. 